\title{
개도국 일자리 창출 지원 사업의 유형과 평가
}

\section{목 차}

I . 서론

II . 개도국 일자리 창출 유형과 논의

III. 개도국 일자리 창출 사업 사례와 분석

IV . 사업 사례의 유형별 평가

$\mathrm{V}$. 정책제언 및 시사점

\section{I . 서론}

개발협력 과정에서 공여국과 국제기구는 개도국의 일자리 창출 사업의 중요성에 대해 다양한 연구와 사업 지원을 수행하고 있다. 예를 들어 국제노동기구(ILO)는 2012년 Post-2015 개발 아젠다, 'Beyond the MDGs: It's all about jobs and livelihoods'를 통해 개발협력과정에서 일자리 만들기(job creation)와 사회보호(social protection)를 최우선 해결과제로 삼아야 한다는 점을 강조하고 있다(ILO 2012). 이는 국제사회의 Post-2015 논의 지형에서 일자리 창출을 통한 성장(job-creating growth)과 사회보호(social protection) 개념이 상호 결합되어 강조되어야 한다는 주장으로 이어지고 있다. 또한 $\mathrm{ILO}$ 사무총장 가이 라이더(Guy Ryder)는 '일자리 창출이야 말로 글로벌개발사업 중 가장 중요한 현안이며, 정당하고 괜찮은 일자리 창출이야 말로 지구상에서 빈곤을 없애고 동시에 경제적 성장도 이룰 수 있는 가장 최선의 방법'이며, 따라서 '일자리는 곧 개발을 의미(Jobs mean development)함' 을 강조했다.

한편 UNDP는 '빈곤층을 위한 녹색일자리(Green Jobs for the Poor)'라는 접근을 통해 새로운 일자리창출의 가능성에 주목하고 있으며, 더 나아가 개도국 내 '환경적인 공적고용프로그램 (environmental public employment programme)'의 가능성을 언급하고 있다. 또한 2008년 보고서를 
통해 고용증대와 빈곤감소를 위한 새로운 모델로서의 사회적 기업(Social Enterprise: A new model for poverty reduction and employment generation)'을 언급하기도 했다. UNDP는 이 보고서를 통해 유럽의 사회적 기업 경험과 모델이 개도국 지역 커뮤니티의 활성화, 사회적 일자리 창출, 빈곤의 효과적이고도 혁신적인 감소 프로그램 수행에 큰 시사점을 줄 수 있다고 판단하고 있다(UNDP, 2008).

현실적으로 개도국을 중심으로 높은 노동시장 진입 장벽이 존재 하고 있으며, 특히 청년층은 노동시장 진입 후에도 상대적으로 쉽게 이탈되는 현상이 심각하게 대두하고 있다. 이는 장기적 관점에서 개도국 사회 불평등과 발전 불균형, 만성적 저개발의 구조적 원인으로 자리 잡고 있다고 분석되고 있다. 사회경제학적으로 일자리 부재, 장기실업, 구직포기, 열악한 일자리 확산 등은 이를 해결하기 위한 '사회적 비용'의 증가를 가져오며, 이는 종종 사회적 갈등으로 표출되기도 한다. 이러한 요인들은 선진국 보다는 개도국에서 보다 더 경제성장과 사회개발의 가능성을 약화시키는 요인으로 작용하고 있으며, 때로는 '빈곤의 덫'에 머무르게 하는 결정적 원인으로도 작용하고 있다.

이러한 맥락에서 본 글은 개도국 일자리 창출 지원 사업의 중요성을 환기시키며, 그간 수행되었던 해당 사업사례 분석을 통해 시사점 도출과 향후 정책제언을 하고자 한다. 사업사례 분석은 일자리 창출과 관련된 개도국 내 직업훈련교육(VET)사업, 기업의 사회적 책임(CSR) 관련 일자리 창출 사업, 그리고 단기 기술이전을 통한 일자리 창출 사업을 중심으로 하되, $\mathrm{KOICA}$ 지원 사업을 위주로 이루어 졌다.1)

\section{II . 개도국 일자리 창출 유형과 논의}

일자리 창출 관련 연구 방향과 그 범위를 정리해 보면 크게 다섯 가지 경향으로 요약될 수 있다. 첫째, 일자리 창출 모범사례와 다른 국가 적용 - 적응 가능성에 대한 연구이다. 이는 선진 공여국의 모범적인 일자리 창출사업 사례와 개도국 적용가능성에 대한 연구로, 국제적 수준의 일자리 창출 혹은 사회적 기업의 개도국 진출 가능성에 대한 관심 속에 수행되었다. 둘째, 일자리 창출 사업이 실제로 고용시장 활성화와 취업률 상승에 얼마나 기여 했는가에 대한 연구이다. 즉, 일자리 창출이 해당 국가 내부 노동시장의 활성화에 기여했는지, 일자리의 창출 과정은 적절한지에 대한 연구이며, 관련하여 사업내용의 차별성, 전달체계의 적절성 등도 관심사이다. 세 번째는, 기업 경영적 관점으로, 일자리 창출과 기업의 정착, 발전 가능성에 대한 연구이며, 특히 사회적 기업의 발전 가능성에 대한 연구가 활발히 수행되었다. 해당 연구들은 주로 기업의 경영성과와 고용성과, 참여기관의 경영역량 등을 평가하고 이를 통해 사회적 기업의 지속· 성공가능성을 진단한다. 넷째, 일자리 창출의 경제적인 파급효과에 대한 연구이다. 즉, 공적 재원을 투자한 일자리 창출 사업이 경제성장에 미치는 영향 등에

1) 본 글의 사업 사례는 이영현(2013), 직업훈련 프로그램 종합평가 보고서: 베트남 사례를 중심으로, KOICA, 주성수, 김성현(2014), 글로벌 CSR의 개발협력 현황과 발전과제: 국내외 사례 비교분석, KOICA, 김성규(2013), 개도국 일자리 창출 사업 지원 방안 연구, $\mathrm{KOICA}$ 의 연구 결과를 중심으로 언급되었다. 
대한 연구이다. 이에 대해서는 긍정론과 회의론이 있는 바, 예를 들어 공적 주체의 일자리 창출과 노동 시장 개입은 장기적으로 경제성장 저해 혹은 경제구조와 시장 논리를 왜곡한다는 신자유주의 입장과 이에 대한 반론이 존재한다. 다섯째, 일자리 창출정책을 국가의 사회보호정책과 노동시장 정책의 단점을 보완하는 새로운 탈 빈곤정책 패러다임, 친 빈곤층 성장(Pro-Poor Growth)정책의 기반으로 이해하는 연구가 있다. 이러한 시각은 일자리 창출 정책을 ‘빈곤층의 노동시장 진입 정책의 일환’으로 파악하고 있다.

$<$ 표 1> 개도국 일자리 창출 관련 연구 시각과 범위

\begin{tabular}{|c|c|}
\hline 연구시각 & 범위와 내용 \\
\hline $\begin{array}{l}\text { 성공 모델의 } \\
\text { 적용가능성 }\end{array}$ & $\begin{array}{l}\text { 선진 공여국의 모범적인 일자리 창출사업 사례와 개도국 적용가능성 } \\
\text { 국제적 수준의 일자리 창출 혹은 사회적 기업의 개도국 진출 가능성 }\end{array}$ \\
\hline $\begin{array}{l}\text { 일자리 창출과 } \\
\text { 고용시장 활성화 }\end{array}$ & $\begin{array}{l}\text { 일자리 창출의 내부 노동시장 활성화 기여도 } \\
\text { 일자리의 창출 과정의 적절성 } \\
\text { 사업내용의 차별성, 전달체계의 적절성 }\end{array}$ \\
\hline 기업 경영적 관점 & $\begin{array}{l}\text { 일자리 창출과 기업의 정착, 발전 가능성 } \\
\text { 사회적 기업의 발전 가능성 } \\
\text { 기업의 경영성과와 고용성과, 참여기관의 경영역량 등을 평가, } \\
\text { 이를 통한 사회적 기업의 지속·성공가능성 진단 }\end{array}$ \\
\hline $\begin{array}{l}\text { 일자리 창출과 } \\
\text { 경제적 파급효과 }\end{array}$ & 공적 재원이 투자된 일자리 창출 사업이 경제성장에 미치는 영향 \\
\hline $\begin{array}{l}\text { 탈 빈곤정책 패러다임, } \\
\text { 친 빈곤층 성장 } \\
\text { (Pro-Poor Growth) 관점 }\end{array}$ & $\begin{array}{l}\text { 일자리 창출 정책을 ‘빈곤층의 노동시장 진입 정책의 일환’으로 파악 } \\
\text { 일자리 창출과 빈곤층 노동시장 진입과의 연관성 }\end{array}$ \\
\hline
\end{tabular}

출처: 김성규, 2013a: 12

개도국 내 일자리 창출이 가지는 사회경제적 의미는 다음 몇 가지로 정리될 수 있다. 첫째, 개도국 일자리 창출 사업은 좁은 의미로는 빈곤지역의 사회적 욕구충족을 통한 지역사회발전과 넓은 의미로는 빈곤계층의 노동시장 진입 이라는 두 가지 목표를 동시에 달성할 수 있는 프로그램으로 이해될 수 있다. 즉, 일자리 창출이 개도국 빈민, 취약계층의 사회서비스 욕구를 해소하는데 기여하며, 동시에 여성, 고령자, 빈곤층 등 이른바 사회 취약계층의 노동시장 진입에도 도움을 준다는 것이다. 둘째, 창출되는 일자리는 이른바 '사회적 일자리(social job)', '괜찮은 일자리(decent work)'를 지향한다. 이 개념은 가치 지향적이며, 특히 일자리의 '지속 가능성'에 특히 주목한 것이며, 이를 통해 개도국 빈곤, 취약계층이 '저 숙련, 단순노동'의 트랩에 머무는 구조가 개선될 수 있다. 이러한 주장은 개도국 내 사회적 일자리(social job), 괜찮은 일자리(decent work) 형성에 회의적인 분석, 즉 개도국 노동시장은 결국 저임금 노동시장 구조이며, 이는 중 - 장기적으로 노동시장과 사회구조의 양극화 문제를 오히려 가속화시킨다는 주장에 대한 반론으로 제기되고 있다. 셋째, 일자리 창출이 개발협력과정에서 공여국 민간기업의 글로벌 CSR사업을 통한 활발한 개도국 진출, 현지 사업파트너십 구축, 사업 확장의 담론 하에 논의되기도 한다. 그런데 이러한 분위기와 방향성에 대한 비판적 점검은 필요하다. 즉, 공여국 
관점의 글로벌 기업 활동과 이에 따른 일자리 창출 사업 모델이 개도국의 사회, 경제, 문화적 맥락에 맞게 적용, 적응 될 수 있는지에 대한 고민이 절대적으로 필요하다. 서구의 성공 모델은 그 나라의 역사적, 제도적, 문화적 전통의 맥락에서 이해되어야 하며, 따라서 개도국 일자리 창출 사업이 '괜찮은 고용(decent employment)'으로 이어지는 효과성을 가지기 위해서는 공여국의 지원 전략이 수원국의 고용 정책과 전략, 노동시장 성격과 구조, 거버넌스 형성 정도, 시민사회의 동의 등과 조응해야 한다는 점을 인정해야 한다.

다음으로 일자리 창출 유형과 이에 따른 사업의 특징, 이를 바탕으로 개도국 적용 가능 사업에 대한 논의를 정리해 보고자 한다. 일반적으로 일자리가 형성되는 방식과 그 효과에 따라 크게 직접 일자리 창출과 간접 일자리 창출로 구분할 수 있으며, 일자리 창출방식과 전략은 국가의 고용정책 방향과 주력 사업 설정에 큰 영향을 받는 것이 사실이다.

직접 일자리 창출 사업에는 현금이전, 창업지원, 고용서비스 등의 사업 종류가 존재하며, 현금이전은 취로 사업 등을 포함한 공익근로, 고용 장려금 지급, 세금감면 등의 형태로 이루어진다. 이는 현재 남미를 비롯한 개도국에서 조건부 현금이전 사업(CCT Program)이나 생산적 복지(workfare) 사업 형태로 진행되고 있다. 창업지원은 청년 창업지원, 신기술부문 창업지원, 사회적 기업 창업지원 등의 사업부문을 가지며, 개도국에서는 환경 사업, 협동조합, 커뮤니티 비즈니스 지원 등의 형태로 나타날 수 있다. 산업화가 상대적으로 진전되어 있고 사회경제 인프라가 축적된 개도국을 중심으로 사회적 기업의 육성 지원 또한 고려될 수 있다. 또한 직접일자리창출 사업 중 고용서비스 영역인 '일자리 매칭 서비스사업'은 한국을 비롯한 서구의 국가들에서는 중점 사업 부문으로 관리되고 있으나, 역량을 갖춘 노동력의 공급(supply of sufficiently quality labour)과 일자리 창출이 불균형한 개도국의 경우 상대적으로 활성화되기 어려운 영역으로 판단된다.

한편 간접 일자리 창출 사업의 대표적인 형태는 직업능력개발 사업이라고 할 수 있다. 통상 이는 기술교육, 직업훈련, 현장 인턴십, OJT(On the Job Training) 등의 사업부문을 가지며, 개도국에서는 노동능력 향상사업, 고용 시장에 맞는 직업훈련원 설립과 운영 지원 등의 형태로 진행되고 있다. 간접 일자리 창출사업 중 고용상담 사업은 실업자나 취업 취약계층에게 취업진로 상담, 취업 정보 제공 등을 통해 이들이 노동시장에서 이탈되지 않도록 하는 역할을 담당하고 있으며, 그 외 실업수당을 통해 실업상태에 빠졌을 때 소득을 일정정도 보전해주는 사업도 넓은 의미에서의 간접 일자리 창출사업 범주에 넣을 수 있다. 국가별로 차별적이긴 하지만 현실적으로 고용상담 사업은 개도국에서 활성화되지 못하고 있는 부문이며, 이는 일정정도 전문지식과 기술력을 갖춘 노동력의 절대 부족에서 기인하기도 한다. 
$<$ 표 2> 일자리 창출사업 유형과 개도국 적용 가능 사업

\begin{tabular}{|c|c|c|c|}
\hline 분류 & 사업유형 & 사업 부문 & 개도국 적용 가능 사업 \\
\hline \multirow{3}{*}{$\begin{array}{l}\text { 직접일자리 } \\
\text { 창출사업 }\end{array}$} & 현금이전 & $\begin{array}{c}\text { 공익근로(취로 사업 등) } \\
\text { 고용 장려금 } \\
\text { 세금감면 혜택 }\end{array}$ & $\begin{array}{c}\text { 조건부현금이전사업 } \\
\text { (CCT Program/Workfare) }\end{array}$ \\
\hline & 창업지원 & $\begin{array}{c}\text { 청년 창업지원 } \\
\text { 신기술부문 창업지원 } \\
\text { 사회적 기업 창업지원 }\end{array}$ & $\begin{array}{c}\text { 친환경 사업 } \\
\text { 취약계층 대상 사회 서비스 } \\
\text { 제공사업(사회적 기업, 협동조합, } \\
\text { 커뮤니티 비즈니스 형태) }\end{array}$ \\
\hline & 고용서비스 & $\begin{array}{c}\text { 일자리 매칭 서비스 } \\
\text { (직업소개, 온라인 잡 매칭 } \\
\text { 서비스 등) }\end{array}$ & - \\
\hline \multirow{5}{*}{$\begin{array}{l}\text { 간접일자리 } \\
\text { 창출사업 }\end{array}$} & 교육시스템 & 초등, 중등 교육시스템 혁신 사업 & - \\
\hline & 직업능력개발 & $\begin{array}{l}\text { 기술교육, 직업훈련, } \\
\text { 현장 인턴십(OJT 등) }\end{array}$ & $\begin{array}{c}\text { 노동능력향상사업 } \\
\text { (노동(고용)시장에 조응하는 } \\
\text { 직업훈련원 설립·운영 지원) }\end{array}$ \\
\hline & 고용상담 & $\begin{array}{l}\text { 취업진로 상담 } \\
\text { 취업 정보 제공 }\end{array}$ & - \\
\hline & 실업소득 지원 & 실업수당 & - \\
\hline & 기타 & $\begin{array}{c}\text { 직업체험서비스 } \\
\text { (한국, 일본, 독일 등의 잡 월드 등) }\end{array}$ & - \\
\hline
\end{tabular}

출처: 김성규, 2013a: 23

개도국 일자리 창출 관련 공여기관별 중점 수행사업을 보면, 차별화되는 경향을 볼 수 있다. 예를 들어 SIDA는 아프리카 사하라이남 지역공동체 활성화, 협동조합 조직화, 빈곤지역 민간자본 투자유치 지원 사업 등을 통해 직접일자리 창출에 보다 주력하고 있으며, GIZ나 KOICA의 경우는 개도국의 기술교육, 직업훈련원 건립과 프로그램 지원 사업 등을 통해 간접일자리 창출 사업 지원에 보다 집중하고 있다고 판단된다. World Bank, UN, ILO 등 국제기구들은 관련 연구와 사업 지원 등을 통해 청년고용(youth employment) 정책에 대한 개념정립, 지표설정 그리고 대안적 방향을 꾸준히 제시해오고 있다. 특히 ILO는 청년고용문제를 해결하기 위해 개도국의 '노동시장 연계형 청년 직업교육훈련(VET: Vocational Education and Training)'2)의 중요성을 지적하며 베트남에서 관련 시범사업을 수행 중에 있다.

2) 개념적으로 '노동시장 연계형 직업교육훈련’은 해당 국가의 인구구조, 미래 산업구조, 실업상황(지역별, 성별, 교육 수준별), 노동시장 요구 등이 반영된 직업교육훈련시스템을 의미한다. 기존의 직업교육훈련이 ‘ 밀어내기식' 시스템이었다면 연계형은 시장 요구 '반영형' 시스템이라 할 수 있다. 


\section{III. 개도국 일자리 창출 사업 사례와 분석}

일자리 창출과 관련된 개도국 내 사업 사례는 크게 간접 일자리 창출 사업 유형과 직접 일자리 창출 유형으로 구분될 수 있으며, 분석과 평가는 간접 일자리 창출 사업 유형을 대표하는 직업훈련교육 (VET)사업을, 직접 일자리 창출 유형으로는 기업의 사회적 책임(CSR) 관련 일자리 창출 사업과 단기 기술이전을 통한 일자리 창출 사업을 중심으로 수행되었다.

\section{1) 직업훈련교육(VET)사업 평가 ${ }^{3)}$}

이번 장에서는 $\mathrm{KOICA}$ 가 수행한 24개 직업훈련사업 평가 결과를 바탕으로 향후 평가와 직업 훈련사업의 방향성을 고민해 보고자 한다. 수행된 평가 결과를 보면, '스리랑카 자프나 기능대학 개선사업'을 제외하고는 대체로 양호한 등급을 받았다. 아시아 지역에는 미얀마 따가야 직업훈련역량 강화사업, 한 · 라오스 직업훈련원 건립사업, 베트남 퀴논 직업훈련원 지원 사업이, 중남미 지역은 과테말라 청소년 직업훈련원 자동차 정비 훈련센터 건립사업, 아프리카 지역 모로코 자동차정비 직업훈련원 건립사업이 그리고 중동지역에는 요르단 국가 직업훈련역량 강화사업이 '매우 성공적' 이라는 평가를 받았다. 전체 평가 사업 중 코스타리카 우에따르 노르떼 직업훈련원 지원 사업이 가장 높은 점수를 받았다. 종합하면 24개 평가 사업 중, 7 개 사업이 '매우 성공적', 12 개 사업이 '성공적', 4 개 사업이 '부분 성공적' 그리고 1 개 사업이 '미흡'의 평가를 받아 전체적으로 KOICA의 해당 지원 사업은 '성공적'이라고 평가될 수 있다.

지원 사업의 지역적 분포를 보면, 전체 24 개 평가 사업 중 아시아 지역이 13 건으로 가장 많았으며, 아프리카 지역이 8 건, 그 외 중남미 2건, 중동지역 1건으로 지역적 편차는 뚜렷했다. 주요 결과를 요약하면 다음과 같다.

$<$ 표 3> 직훈 사업별 평가 종합결과

\begin{tabular}{c|c|c|l|c}
\hline 지역 & 평가 종류 & 시기 & \multicolumn{1}{|c|}{ 사업 명 } & 최종 등급 \\
\hline 아시아 & 사후평가 & 2012 & 방글라데시 미르푸르 직업훈련원 개보수 및 역량강화 사업 & $\begin{array}{c}9 \\
\text { (성공적) }\end{array}$ \\
\hline 아시아 & 종료평가 & 2011 & 미얀마 따가야 직업훈련역량 강화사업 & $\begin{array}{c}11 \\
\text { (매우성공적) }\end{array}$ \\
\hline 중동 & 종료평가 & 2011 & 요르단 국가 직업훈련역량 강화사업 & $\begin{array}{c}11 \\
\text { (매우성공적) }\end{array}$ \\
\hline 아시아 & 종료평가 & 2011 & 스리랑카 자프나 기능대학 개선사업 & $\begin{array}{c}6 \\
\text { (미흡) }\end{array}$ \\
\hline 아시아 & 종료평가 & 2009 & 라오스 한라 직업훈련원 역량강화사업 & $\begin{array}{c}10 \\
\text { (성공적) }\end{array}$ \\
\hline
\end{tabular}

3) 이영현(2013), 직업훈련 프로그램 종합평가 보고서: 베트남 사례를 중심으로, KOICA 분석 결과를 참고함. 


\begin{tabular}{|c|c|c|c|c|}
\hline 지역 & 평가 종류 & 시기 & 사업 명 & 최종 등급 \\
\hline 아시아 & 종료평가 & 2009 & 인니 자카르타 기술문화협력센터 건립사업 & $\begin{array}{c}10 \\
\text { (성공적) }\end{array}$ \\
\hline 중남미 & 종료평가 & 2009 & 과테말라 청소년 직업훈련원 자동차정비 훈련센터 건립사업 & $\begin{array}{c}11 \\
\text { (매우성공적) } \\
\end{array}$ \\
\hline 아시아 & 종료평가 & 2009 & 한·베 산업기술학교 증축 및 역량강화사업 & $\begin{array}{c}10 \\
\text { (성공적) }\end{array}$ \\
\hline 아시아 & 사후평가 & 2008 & 한·필리핀 다바오시 직업훈련원 건립사업 & $\begin{array}{c}10 \\
\text { (성공적) } \\
\end{array}$ \\
\hline 아프리카 & 사후평가 & 2008 & 이집트 알렉산드리아 자동차정비 직업훈련원 지원 사업 & $\begin{array}{c}9 \\
\text { (성공적) }\end{array}$ \\
\hline 아시아 & 사후평가 & 2007 & 한·라오스 직업훈련원 건립사업 & $\begin{array}{c}11 \\
\text { (매우성공적) }\end{array}$ \\
\hline 중남미 & 사후평가 & 2007 & 코스타리카 우에따르 노르떼 직업훈련원 지원 사업 & $\begin{array}{c}12 \\
\text { (매우성공적) }\end{array}$ \\
\hline 아프리카 & 사후평가 & 2007 & 모로코 자동차정비 직업훈련원 건립사업 & $\begin{array}{c}11 \\
\text { (매우성공적) }\end{array}$ \\
\hline 아시아 & 사후평가 & 2004 & 베트남 퀴논 직업훈련원 지원 사업 & $\begin{array}{c}11 \\
\text { (매우성공적) }\end{array}$ \\
\hline 아시아 & 사후평가 & 2004 & 베트남 하노이 직업훈련원 지원 사업 & $\begin{array}{c}10 \\
\text { (성공적) }\end{array}$ \\
\hline
\end{tabular}

출처: 이영현, 2013: 28 29, 저자 재구성

사업평가는 $\mathrm{OECD/DAC평가} \mathrm{기준을} \mathrm{적용하여} \mathrm{수행되었으며,} \mathrm{평가계획} \mathrm{및} \mathrm{평가지표개발을} \mathrm{위한}$ 사전조사 및 문헌연구뿐만 아니라 표본조사, 면담조사를 위한 현장조사를 포함했다. 평가 항목은 적절성, 효과성, 효율성, 영향력 그리고 지속 가능성 등이 설정되었으며 각 항목 당 세부 평가기준을 적용했다. 적용된 사업평가 항목 및 세부 평가 기준을 정리하면 다음과 같다.

\section{$<$ 표 4> 사업 평가항목 및 세부평가 기준}

\begin{tabular}{c|l}
\hline 항목 & \multicolumn{1}{c}{ 평가기준 } \\
\hline 적절성 & $\begin{array}{l}\text { 아국 및 수원국 우선순위 부합성 } \\
\text { 사업지역/수혜자의 필요와 일치 }\end{array}$ \\
\hline 효과성 & 의도한 목표의 달성도가 $80 \%$ 이상/ $50 ~ 80 \% / 50 \%$ 미만 \\
\hline 효율성 & $\begin{array}{l}\text { 계획 대비 사업비용이 } 100 \% \text { 또는 이내/ } 100 ~ 150 \% / 150 \% \text { 이상 집행 } \\
\text { 계획 대비 사업 수행기간이 } 100 \% \text { 또는 이내/100 150\%/ } 150 \% \text { 이상 소요 }\end{array}$ \\
\hline 영향력 & $\begin{array}{l}\text { 상위목표 달성가능성 } \\
\text { 사업의 역량개발 및 제도강화 기여도 }\end{array}$ \\
\hline 지속가능성 & $\begin{array}{l}\text { 제도적(구조, 기술, 인적자원) 가능성 } \\
\text { 재정적(운영 및 유지보수) 가능성 }\end{array}$ \\
\hline
\end{tabular}

출처: KOICA, 평가실 
평가수행 팀은 각 항목 당 사업 평가 결과를 요약하고 있는데, 우선 적절성 측면에서는, 아국 개발정책 및 우선순위 부합성에 대한 분석이 실시된 12 개 사업 중 9 개 사업(75\%)이 부합하며, 수원국 개발정책 및 우선순위는 24개 사업 중 23개 사업(96\%)이 부합한다고 진단하고 있다. 또한 사업 기획 당시 사업지역 및 수혜자의 필요와 일치 여부는 24 개 사업 중 16 개 사업(67\%)이 일치한다고 요약하고 있다. 효과성 측면에서는 24 개 사업 중 16 개 사업(67\%)이 의도한 목표의 $80 \%$ 이상, 7 개 사업(29\%)이 의도한 목표의 50 80\%를 달성했으며, 효율성 측면에서는 24 개 사업 중 14 개 사업 $(56 \%)$ 이 계획된 기간 및 예산 내에서 사업을 수행하였다고 판단했다. 한편, 영향력 측면에서는 '직업훈련원에 대한 사회적 인지도 증가로 인한 취업기회 및 고용기회가 증대되었고 관련 산업체들의 직업훈련원 졸업생들에 대한 기대가 상승하였다'라고 평가하고 있다. 그런데 이 부분에 대한 정량적인 판단 기준은 다소 모호할 수 있다. 즉 사회적 인지도의 증가가 곧 노동시장에서의 취업기회 및 고용 기회로 확대로 이어지는 것은 아니기 때문이다. 따라서 취업 기회 및 고용기회가 노동시장에서 어느 정도 증대되었으며, 이러한 변화가 직업훈련사업 지원에서 기인하는 것인지에 대한 점검이 필요하다. 이는 사업 초기 이러한 변화를 모니터링, 평가 할 수 있는 장치가 마련되어야만 가능할 수 있다. 또한 평가는 '산업체-학교-정부 간 협력체계 구축에 기여하였고 양질의 연수환경을 조성하여 제도 내실화에 기여하였으며, 타 기관에 대한 전달교육으로 직업훈련 관련 교육 및 교재 등의 확산효과가 있었다'고 진단하고 있다. 확산 효과성에 대한 평가는 타당할 수 있지만 확산성 또한 보다 정량적이고 '노동시장 환경 변화를 반영하는' 평가 지표마련이 필요해 보인다. 그 외 지속가능성 측면에서는, 24 개 사업 중 19 개 사업(79\%)이 제도적 지속가능성이 있고 14 개 사업(58\%)이 재정적 지속가능성이 있다고 평가했다.

종합적으로 보면, 직업훈련사업의 결과를 평가함에 있어 가장 중요한 지표는 직업훈련기관의 사회적 영향력, 즉 직업훈련기관이 노동시장의 요구를 얼마나 현실적으로 반영하고 있으며, 실제로 졸업생이 노동시장에 얼마나 성공적으로 진입하고 있는가라고 할 때 이러한 점의 분석이 정치하게 이루어지지 못한 한계가 지적되어야 한다고 보여 진다. 이는 사업의 목표 설정이 직업훈련기관이 해당 개도국 노동시장에 미치는 영향력을 고려하기 보다는 기관 역량강화 자체에 머물고 있음에도 기인한다.

평가를 바탕으로 한 제언 중 일자리 창출과 관련된 몇 가지를 요약해 보면, 첫째, 직업훈련 분야에 대한 전략은 $\mathrm{KOICA}$ 의 해당 분야에 대한 강점과 약점을 바탕으로, 사업을 통해 달성하고자 하는 $\mathrm{KOICA}$ 의 전략적 목표가 직업훈련 분야에 특화되어 제시되어야 한다는 점이다. 둘째, 수원국의 직업훈련 분야 정책 및 전략 보유 여부와 관계없이 수원국 직업훈련 분야 이슈, 체계, 거버넌스 구조 등을 사업 기획단계에서 고려해야 하며, 셋째, 해당 프로그램 및 사업 수준의 체계적인 성과관리의 필요성이다. 수원국의 노동시장 정보 및 $\mathrm{M} \& \mathrm{E}$ 시스템이 충분히 발달되어 있지 않은 경우, $\mathrm{KOICA}$ 현지 사무소를 중심으로 이를 보완하기 위한 별도의 M\&E 방안이 강구되어야 한다는 제언은 타당해 보이며, 마지막으로 노동시장 수요를 반영한 커리큘럼의 개발에 대한 지적은 적절하다. 해당 제언과 관련하여 향수 직업교육 커리큘럼에 '노동시장 요구를 어떻게 반영할 수 있는가'에 대한 고민은 중요 과제로 남겨져 있다.

제언 사항을 중심으로 강조점을 정리해보면, 사업은 결국 개도국의 고용과 연계되며 노동시장의 요구를 반영하는 양질의 교육훈련을 제공을 목표로 설계, 형성되어야 하며 이를 위해 수원국의 
노동시장 정보 및 $\mathrm{M} \& \mathrm{E}$ 시스템을 충분히 활용할 수 있어야 한다. 해당 시스템이 충분히 발달되어 있지 않은 경우, $\mathrm{KOICA}$ 현지 사무소를 중심으로 이를 보완하기 위한 별도의 $\mathrm{M} \& \mathrm{E}$ 방안이 강구되어야 한다는 점은 설득력을 가진다. 결국 사업의 내용적 측면에서는 노동시장 수요를 반영한 커리큘럼의 개발, 교사 역량 강화, 시설 및 기자재 개선이 필요하며, 사업의 평가 측면에서는, 기초선 조사 단계에서 직업훈련기관이 해당국가의 일자리 창출에 미치는 영향력에 대한 M\&E 지표설정이 고민되고, 이러한 요소가 사업설계, 형성에 반영되어야 한다는 점이다.

정책제언과 관련하여 베트남의 직업교육훈련 사업 사례를 언급해 보고자 한다. 베트남의 직업교육훈련기관 프로그램은 대다수가 이론 위주의 수업으로 진행되었으며, 여기에 유교적 전통 하에서 대학진학의 중요성 강조되며, 직업훈련학교는 성적이 낮은 학생이 진학하는 곳이라는 사회적인 인식 등으로 인해 직업교육훈련이 전반적으로 활성화되어 있지 못했다. 이로 인해 고용시장과 기업의 요구에 부합하는 직업교육은 이루어지고 있지 못하며, 관련 교육훈련을 수료한 청년들도 실질적인 취업기회를 얻지는 못하고 있다. 결국 베트남의 일자리 문제, 특히 청년고용문제는 낙후된 직업교육훈련 시스템에서도 상당부문 기인한다고 볼 수 있다. 즉 일자리 공급의 문제가 크게 대두되었다.

개도국 일자리 문제 해결을 위한 방법으로 몇 가지 방안이 제시되고 있는데, 첫째, 전달체계의 합리화를 꼽을 수 있다. 이는 일자리 미스 매칭구조의 개선, 인력 수급 전망체제 개선을 의미한다. 둘째는 노동시장과 기업의 요구에 맞는 맞춤형 직업교육훈련 과정과 내용 구축이다. 새로운 커리큘럼의 구성과 이를 해당 국가의 중장기 교육과정, 혹은 단기 맞춤형 직업기술교육에 반영 할 수 있다. 세 번째는 노동시장 내 경력자 혹은 탈락자들을 위한 현장경험, 실습을 통한 인턴십, 현장직무훈련(OJT) 등의 활성화 방법이 있다. 그런데 노동시장 필요인력 분석을 해 보면 일자리의 문제가 직업교육훈련시스템과 노동시장간의 연계부족에서 기인함을 알 수 있다. 이러한 맥락에서 베트남에서는 두 번째와 세 번째 방안이 청년고용활성화에 보다 실질적이며 효과적으로 기여할 수 있는 방안이라고 할 수 있다. 이는 이른바 ‘노동시장 연계형', ‘기업 맞춤형’ 직업교육훈련이라는 개념으로 범주화할 수 있다.

그런데 이른바 '연계성 강화’를 위해서는 노동시장과 청년고용실태의 과학적인 분석과 모니터링, 이를 위한 기법 개발, 관련 자료의 축적 등 기반 작업이 요구된다. 즉, 일자리문제는 과학적인 원인분석을 바탕으로 각국의 경제수준, 지식기반 사회라는 세계적 추세 등을 종합적으로 고려하여 대안을 모색해야 한다. 이를 위해 예를 들면, 교육과정 졸업자 혹은 취업예정자 관련 데이터 베이스의 구축, 이들의 직업 이동경로 추적조사와 자료화 등이 필요하다. 이는 국가의 인력수급계획, 실업문제 포함 인적자원의 효율적 양성과 활용에 중요하게 활용될 수 있다.

이러한 맥락에서 $\mathrm{ILO}$ 의 새로운 직업훈련교육 프로그램을 주목할 필요가 있는데, ILO는 하노이 사무소를 통해 베트남 중앙정부와 함께 (1) 직업훈련의 예산 증액관련 해당 법 개정과 (2) 기업과 노동시장의 요구에 맞는 이른바 ‘맞춤형 직업훈련 시스템’ 구축에 노력하고 있다. 특히, G20의 직업훈련 육성 전략에 의거, 베트남 경제와 연관된 관광부문 등 새로운 분야에 대한 직업훈련을 특화시키려 하고 있다. 이를 위해 (1) 후에(Hue) 인근 광남(Quang Nam), (2) 호치민시 인근 동나이(Dong Nai), (3) 딘즈엉(Dinh Duong) 지역의 특정 직업훈련 관련 학교를 선정, 커리큘럼을 포함한 관련 프로그램을 
디자인하고 있으며, 이는 2014년에 구체화될 계획에 있다. 그런데 직업훈련 기관의 운영과 프로그램 설정 과정에 무엇보다 민간기업의 참여를 유도할 필요가 있다는 주장이 설득력 있게 제기되고 있는데, 기업의 참여는 기업이 가지고 있는 재원, 노하우, 인턴십 기회의 활용측면에서 강점을 가지며, 인력 양성프로그램과 민간기업 활동이 부합할 때 사업은 시너지 효과를 가질 수 있기 때문이다.

\section{2) 기업의 사회적 책임(CSR)을 통한 일자리 창출 사업}

국내 기업의 사회적 책임(CSR)을 통한 일자리 창출은 그 사례가 매우 제한적이다. 이는 CSR 사업이 주로 일회적, 기업홍보성 그리고 자선적 사업으로 이루어지는 경향이 있으며, 기업의 주력 사업 업종과는 무관한 부문에서 지원을 하는데 에서도 기인하고 있다. 그만큼 CSR을 통한 일자리 창출은 기업들이 개발협력의 성과로 내기 어려운 부문이라고 보여 진다.

$\mathrm{CSR}$ 을 통한 개도국 일자리 창출에 기여한 국내 기업으로는 삼익악기의 사례가 꼽힌다. KOICA 와 공동사업을 통해 인도네시아 현지 일자리가 3 천개 이상 창출되었다고 보고되고 있으며, 이른바 '현지 기업'으로 정착되고 있다고 평가되고 있다. 또한 연간 2회의 기술교육훈련을 실시해, 목공예반 60 명, 피아노조율반 40 명, 제빵과 봉제 20 명 등을 대상으로 우수수료생에게는 삼익악기에 채용하는 프로그램을 갖고 있다. 기술교육과 직무적응 훈련을 통과한 수료생들 중 본인이 희망하고 직업훈련 교사 및 실무적응훈련 슈퍼바이저가 추천하는 졸업생은 삼익 인도네시아에 채용될 수 있는 기회를 갖는다는 것이다.

그런데 이러한 선순환 구조가 해당 국가 경제상황의 변화라는 변수에 크게 영향을 받을 수 있다는 점, 따라서 그 지속가능성에 의문을 제기하는 평가 또한 존재한다. 즉, 현지에서 채용된 직원의 고용 상태가 점검되어야 하는데, 만약 불경기나 경제위기 시 현지 채용된 직원들이 쉽게 해고, 정리 될 수 있는 일자리라면, 해당 CSR 사업을 통해 양질의 일자리가 생성되었다고 단언하기는 어렵기 때문이다. 또한 기술교육훈련 프로그램도 훈련생이 투자한 시간과 비용 대비 그 효과성과 예측가능성이 확보될 때 비로소 자리 잡을 수 있을 것이다.

<표 5> 국내외 기업의 사회적 책임(CSR) 사업 평가

\begin{tabular}{c|c|c|c}
\hline & 기술 훈련 & 고용 창출 & 소득 증대 \\
\hline 삼익악기 & 강 & 강 & 중 \\
\hline 세아상역 & 강 & 강 & 중 \\
\hline SK 이노베이션 & 중 & 중 & 중 \\
\hline General Mills & 강 & 강 & 강 \\
\hline Kraft Foods & 중 & 강 & 중 \\
\hline L'Oreal & 중 & 중 & 중 \\
\hline Natura & 강 & 강 & 강 \\
\hline Abbott Lab & 강 & 중 & 중 \\
\hline
\end{tabular}




\begin{tabular}{c|c|c|c}
\hline & 기술 훈련 & 고용 창출 & 소득 증대 \\
\hline Novartis & 강 & 중 & 중 \\
\hline Pfizer & 강 & 중 & 중 \\
\hline SCJohnson & 강 & 중 & 중 \\
\hline Sumitomo Chemical & 강 & 강 & 중 \\
\hline TWI & 강 & 중 \\
\hline Columbia Sports & 강 & 강 & 중 \\
\hline Levi Strauss & 강 & 강 & 중 \\
\hline Marks\&Spencer & 강 & 중 & 강 \\
\hline Walmart Mexico & 강 & 강 & 중 \\
\hline Celtel Congo & 강 & 강 & 강 \\
\hline ITC & 강 & 강 \\
\hline Agility & 강 & 중 & 중 \\
\hline E3Empower & 강 & 중 & 중 \\
\hline Newmont & 강 & 강 & 중 \\
\hline SolarNow & 강 & 강 & 중 \\
\hline
\end{tabular}

출처: 주성수, 김성현, 2014

또 다른 국내 기업의 사례로서는 세아상역이 언급된다. 이 기업은 빈곤국가의 빈곤층을 노동자 고용을 통한 빈곤감소와 기업이 필요로 하는 안정적인 고용 인력의 확보라는 두 가지 목표를 동시에 달성하고 있으며, 이는 결국 지역사회 경제에 기여하는 비즈니스 전략을 추진한다는 점에서 CSV 모델에 해당 된다는 평가를 받기도 한다. 이는 2011년 대지진으로 26만 명의 사망자를 냈던 아이티에 세아상역이 의류공장을 건설해 시장을 개척한 '전략적' CSR 사례로, 북부지역에 산업단지를 조성해 2014년 현재까지 공장을 건설, 가동하며 여성 등 빈곤층과 취약층에게 일자리를 제공하여 이들의 안정적인 소득 보장과 빈곤탈출을 돕고 있다. 2012년부터 8만5천 달러를 투자해 2014년까지 제 2 , 제 3 공장들을 북부지역 산업단지에 조성해 수 천 개의 일자리를 제공하며, 직원들의 복리후생 차원에서 직장 내 뿐만 아니라 직장 주변의 학교, 훈련센터, 고아원 지원 등 지역사회에 대한 투자를 지속해 오고 있다.

세아상역은 한국과 미국 포함 전 세계 10 개 국가에 22 개 현지 법인과 34 개 공장을 운영, 약 3 만 5 천 명의 직원이 근무하고 있는 글로벌 섬유기업으로, 주력 업종의 성격과 개도국 내 잉여 노동력의 결합이 용이한 점이 일자리 창출에 기여할 수 있는 주요한 요인으로 판단된다. 향후 안정적이고도 양질의 일자리 창출, 확대 여부가 사업의 지속 가능성과 표방하고 있는 사회적 책무를 수행하는데 있어 관건이라 할 수 있다. 


\section{3) 기술 이전을 통한 직접 일자리 창출 사업}

\section{가. 자동차 정비기술 교육을 통한 일자리 창출(가나)}

$\mathrm{KOICA}$ 와 현대자동차가 수행한 '자동차 기술 교육 센터 건립 운영을 통한 가나 청소년 역량강화 프로젝트(Empowering Ghanaian Youth through Auto-mechanic skills training)'는 기술 전수를 통한 직접 일자리 창출 사업으로 분류될 수 있다. 사업 대상지는 가나 동부 코포리두아(Koforidua) 지역이며, 사업 대상은 13 24세 청소년, 사업기간은 2011년 12월 2012년 11월이었다. 주요 사업 내용은, (1) 자동차 기술 교육 센터 설립, 설비 지원, (2) 자동차 기술 교육 과정 개발 및 교육, (3) 이를 통한 자동차 정비사 양성, (4) 졸업 후 일자리 창출 지원, (5) 일자리 정보 공유와 센터 발전을 위한 네트워크 형성 지원 등으로 설정되었다.

사업 성과와 의미를 정리해 보면, 첫째, 현지 $\mathrm{NGO}$ 인 플랜 가나, 가나 교육부, 가나교육서비스(Ghana Education Service), 청소년 위원회, 그라티스 재단(GRATIS foundation), 산업부 등 관련 주체들 간의 협력 체제를 구축, 모니터링 구조를 통한 사업의 투명성과 공정성을 확보한 노력이 돋보인다는 점이다. 둘째, 가나의 노동시장이 요구하고 있는 양질의 자동차 정비인력 공급이라는 측면에서 실질적인 성과를 보이고 있다고 판단된다. 셋째, 가나의 자동차 정비기술의 표준화에도 일정부분 기여하고 있다. 넷째, 자동차 정비 교육에서 양질의 실습교육과 현장 학습이 크게 강화되는 등, 가나 기술 교육의 커리큘럼에 새로운 변화를 가져오고 있다는 점이다. 다섯째, 교육훈련센터 사업이 교육의 기회 확대와 일자리 창출을 통해 지역 사회 빈곤퇴치에 기여한다는 점이다.

일자리 창출과의 연관성을 보면, 우선 가나의 고용시장 상황을 고려해야 한다. 가나의 고용시장 상황은 일자리의 공급 부족보다는 노동시장이 원하는 양질의 노동 인력의 절대적 부족 현상이 보다 현저하다. 이런 상황에서 기술훈련센터의 지향점인 양질의 기술훈련을 통한 자영업(자동차 정비업) 육성과 관련 부문 취업 유도가 노동시장 상황과 부합하고 있다고 볼 수 있다. 또한 현지 자동차AS, 정비 공장과의 지속적 연계를 통한 훈련생의 현장교육(OJT) 기회를 제공, 이후 취업과 연결될 수 있는 구조도 큰 장점으로 꼽힌다.

사업의 향후 과제는, 첫째, 검증된 현지 NGO 등의 활용을 통해 실업해소와 일자리 창출을 위한 기술교육의 중요성을 상시적으로 강조하고, 동시에 산업부, 교육부 등 정부 관련 부처의 재정적 지원 확보 노력을 계속 유도해야 한다는 점이다. 둘째, 학교 건물 유지관리, 장비 개· 보수 등 인프라 운영을 위한 대책도 필요하며, 셋째, 사업 지역에 있는 기술 전문대학인 K-poly와의 협약을 통해 드림 센터의 교육 과정과 내용을 지속적으로 모니터링 할 필요가 있다. 넷째, 교육 내용의 지속적인 업데이트와 양질의 교사 확보는 센터 기술학교를 차별화 시키고 졸업생의 취업률을 높이는데 중요한 사항이며 이를 강화해야 한다. 마지막으로 운영되고 있는 기술센터의 장학제도를 좀 더 개선하고 정교화 할 필요성이 있다. 특히 빈곤층과 여성 등 이른바 소외계층을 위한 교육의 기회 확대와 노동시장 진출 활성화 측면에서, 빈곤층 자녀에 대한 장학생 선발은 보다 객관적인 지표 마련과 심사 과정을 통해 이루어져야 할 것이다. 


\section{나. 지역 빈곤퇴치사업을 통한 일자리 창출(모잠비크)}

$\mathrm{KOICA}$ 는 포스코와 함께 모잠비크 마니싸(Manhica) 지역 빈곤퇴치 지원 사업(Antipoverty Program in Manhica, Mozambique)을 2011년 7월부터 2012년 6월까지 수행했다. 사업 내용은, (1) 선진 농업기술 교육, 농기계 교육 실시(이모작, 협동농장), (2) 고부가가치 농산물 재배 및 판매의 활성화, (3) 주변 지역에 적합한 고소득 작물 개발 및 보급, (4) 농업 훈련센터 인근 만찌아니 마을 문맹퇴치 사업, (5) 만찌아니 마을 초등학교 후원사업 등으로 설정되었다.

사업성과로는 첫째, 농업기술의 전수를 꼽을 수 있다. 한국식 벼농사 이앙법 교육, 시범농장을 통한 토마토 재배 기술 전수, 농기계 운전 및 관리 기술 교육, 퇴비 증산법 교육 등이 실시되었다. 둘째, 시범 협동 농장 구성 및 운영이다. 기아대책위와 지역 주민위원회를 통한 농장 운영위원회 구성, 운영 규칙 등이 설정되었다. 훈련생을 5 인 1 조로 나눠 조별 공동 실습 농장을 부여했으며, 조별로 각각의 부지에 양파, 토마토, 양배추, 상추 등을 협력하여 재배케 하는 방법이 정착되었다. 셋째, 농장 인프라 구축이다. 농장 급· 배수 시설 구축, 농업장비(경운기, 이앙기, 트랙터, 콤바인 등) 충원, 창고 건축 등을 꼽을 수 있다. 넷째, 작물재배 및 유통과정이 구축된 점이다. 벼 재배(10ha), 시범농장을 통한 토마토 재배를 실시했으며, 작물의 효과적인 유통 방법 및 판로 개척하였으며, 2011년 12월에 트럭을 구입, 2012년 1 월부터 작물 공동 판매를 시작했다. 다섯째, 지역 일자리 창출 부문이다. 즉, 농장운영을 통해 취업 혹은 일할 수 있는 기회가 마련되었다. 훈련기간 동안 훈련생을 평가하여 훈련 성적이 우수한 사람을 선발, 농장 취업을 의뢰하며, 졸업생들과 함께 공동 경작할 수 있는 공동 농장 운영도 시도하고 있다.

사업의 의미로는, 첫째 현지상황에 보다 조응하는 교육사업의 필요성과 가능성을 확인 했으며, 둘째, 주민들이 공동으로 토지와 노동력을 제공하고 생산물을 통한 수익 배분 구조로의 전환 가능성 확인, 셋째, 농장의 수익구조와 성과를 관리할 수 있는 전문 인력 및 기술 확보 필요성 등의 확인을 꼽을 수 있다.

일자리 창출과의 연관성을 보면, 첫째, 농업훈련원 교육과정을 수료한 학생은 농업훈련원 관리자 및 농업 기술 전문 교사로 양성될 수 있다는 점이다. 또한 인근에 형성되고 있는 공동 농장 경영 총괄 관리자로 활동할 여지도 형성되고 있었다. 둘째, 공동농장 운영을 통한 지역 일자리 창출 측면이다. 창출될 수 있는 부문은 농업 종사자, 유통 및 운송 담당자, 판매망 구축 관련이다. 셋째, 신 농업 기술을 바탕으로 한 자영농 육성 가능성이다. 자영농의 규모가 확대 된다면, 농업 종사, 유통, 판매 부문의 일자리 창출 가능이 높다고 하겠다.

사업의 향후 과제를 정리해보면, 첫째, 추가 실시되는 농업경영과 축산 교육 실습은 일자리 창출과 농가 수익사업, 이를 통한 자영농 활성화 측면에서 의미가 있으며, 따라서 이를 보다 집중적으로 수행해야 하며, 둘째, 지역사회에서 이미 형성되어 있는 문화적, 사회적 특수성을 극복하기 위한 소통의 대안이 마련되어야 한다는 점이다. 셋째, 지역주민 협의체의 구성과 이를 통한 협동 농장의 활성화 모색이 필요하다. 넷째, 공여국 민간 기업을 포함한 수행기관의 지속적인 관심과 모니터링, 특히 운영주체인 현지 $\mathrm{NGO}$ 의 역할과 보다 투명한 운영 원칙 수립이 필요하다. 즉, 공동농장 관련 행정, 농작물 판매, 수익관리 등 전반적 운영 규약과 지침 등을 문서로 수립하는 것이 필요하겠다. 빈곤, 
소외계층을 포함하는 지역 일자리 창출 가능성도 이러한 향후 과제의 이행을 통해 보다 활성화 될 수 있을 것이다.

\section{다. 녹색 산업 지원을 통한 일자리 창출(캄보디아)}

해당 사업의 정식 명칭은 '전기전자제품 처리를 통한 녹색일자리 창출을 위한 민관협력사업 (Creating employment opportunities and ensuring effective e-wast management in Cambodia) 이며 KOICA, 삼성전자, UNIDO가 2012년부터 수행하고 있다. 사업지역은 캄보디아 프놈펜(Phnom Penh), 씨엠립(Siem Reap), 반테이 미안쩨이(Banteay Meanchey), 바탐방(Battambong), 캄퐁참 (Kampong Cham) 지역으로, 이 지역은 인구 밀집지역, 비즈니스 활성지역, 실업률이 매우 높은 지역으로 특징지어진다.

사업 대상은 전기전자 정비 전문가와 일반인을 대상으로 하며, 사업 내용을 보면 (1) 저소득층과 청년실업자, 영세사업자들에게 전기전자폐기물 처리 기술 전수 및 교육훈련 프로그램 실시, (2) 전기전자폐기물의 적절한 관리 체계 구축 및 주민인식제고를 통하여 지속 가능한 환경기반 마련, (3) 워크숍 및 세미나를 통한 다양한 이해관계자들의 공감대 형성 및 협력증진, (4) 지역별 맞춤 전략을 통한 효과적인 폐기물관리 및 일자리창출 등으로 설정되어 있다.

사업과 일자리 창출과의 연관성을 보면, 첫째, 해당 사업은, 민간 기업의 개도국 내 수익모델 창출이라는 목적과 현지 인력의 역량강화와 이를 통한 일자리 창출이 동시에 이루어 질 수 있는 모델이라는 점에서 의미를 가진다. 특히 기업의 입장에서 단순히 투자와 이에 따른 일자리의 제공이라는 단선적인 구도에서 벗어나, 보다 중 - 장기적인 관점에서 필요한 인력을 현지에서 직접 양성하고 이 인력을 다시 활용하는 전략을 취하고 있다는 점에서 특징적이다. 둘째, 양질의 일자리와 단순 노동력이 종사하는 일자리가 명확히 양분된 캄보디아의 노동시장 상황에서 UNIDO, KOICA 그리고 민간 대기업의 해당 프로젝트의 수행과 이로 인한 일자리 창출 과정은 개도국 일자리 창출의 새로운 대안과 그 가능성을 보여주고 있다는 점에서 의미가 크다.

사례 분석을 통해 도출된 사업의 향후 과제를 정리해 보면, 첫째, 전문가 및 일반 정비사 양성 교육의 규모가 보다 확대될 필요가 있다는 점이다. 이는 현지의 요구이기도 하며, 특히 교육과정에 사회 취약계층이 보다 적극적으로 참여할 수 있는 방안이 마련 되여야 한다. 둘째, 기업에게 보다 실질적으로 도움이 되는 기술 교육과 교육생에게는 실질적인 일자리창출 전략이 적용되어야 한다. 민간 기업의 요구와 필요를 수시로 모니터링, 이를 국가 일자리 매칭 사업에 빠르고도 적극적으로 반영하고자 하는 현지 정부 기관의 노력 또한 필요하다. 셋째, 환경사업과 연관된 현지 캄보디아 민간기업의 발굴과 이들과의 일상적 소통, 파트너십 형성 · 확대가 중요하며 이를 통해 교육생의 일자리 또한 안정적으로 확보될 수 있다.

\section{라. 단기 직업훈련을 통한 빈민지역 일자리 창출(몽골)}

$\mathrm{KOICA}$ 와 코피온이 수행한 해당 사업의 정식 명칭은 '몽골 체쯔지역 직업훈련, 일자리 창출 사업 및 아동가족 지원 사업(Vocational Training, Employment Promotion and Children-family Support 
in Chez, Mongolia)'이다. 사업대상지는 몽골 울란바타르 체쯔지역, 사업기간은 2012년 2월부터 2014년 12월까지로 계획되어있으며, 이 중 2011년부터 우선 수행된 1년간의 사업을 분석했다. 해당 사업계획서에 따르면 수혜자는 체쯔지역 취약계층, 여성 및 아동, 가족 등 2000여명으로 설정되고 있다. 시행기관은 코피온과 위스타트 운동본부이며 수원국의 협력 기관은 몽골국제대학(MIU: Mongolia International University)으로 명시되어 있다.

또한 사업은 $\mathrm{MDG}$ 달성과도 밀접한 관련을 가지고 있는데, 즉 목표 1. 극심한 빈곤과 기아퇴치, 목표 2. 초등교육의 확대 목표 3. 성평등 촉진과 여권신장, 목표 5. 모성건강 증진에 해당되며, 이러한 목표달성을 위한 방안으로 다음과 같은 사업 방안을 제시하고 있다.

<표 6> 체쯔지역 사업의 해당 MDG와 달성을 위한 사업 방안

\begin{tabular}{l|l}
\hline \multicolumn{1}{c|}{ MDG } & \multicolumn{1}{c}{ 사업방안 } \\
\hline GOAL 1. 극심한 빈곤과 기아퇴치 & $\begin{array}{l}\text { 직업훈련(이용, 미용, 제빵, 봉제 등)을 통한 소득활동가능 기술보급 } \rightarrow \\
\text { 취업과 창업 유도 }\end{array}$ \\
\hline GOAL 2. 초등교육의 확대 & 아동가족 지원 사업(체쯔지역 문화센터 내 아동 지원프로그램 운영 등) \\
\hline GOAL 3. 성평등 촉진과 여권신장 & 여성대상 직업훈련, 이를 통한 여성의 취업기회 확대 \\
\hline GOAL 4. 어린이, 유아 사망률 감소 & 아동보건서비스 연계를 통한 건강 진단, 확보 \\
\hline GOAL 5. 모성건강 증진 & 임산부 상담과 보건 서비스 제공 \\
\hline
\end{tabular}

출처: 김성규, 2013a: 108

현재 해당 사업은 코피온, 위스타트 운동본부, 몽골 국제대학 직업훈련센터의 3자 협력 사업으로 진행되고 있으며, 주민역량증대, 직업훈련을 위한 강사양성, 직업훈련에 대한 주민의 접근성 증대 등을 지향하며, 이는 결국 기술 보급을 통한 유효 노동 인력의 역량 강화에 주력하고자 함이다.

개도국 일자리 창출의 주요 방향이 잠재적 노동인력의 역량강화와 이를 통한 새로운 일자리의 창출로 설정된다는 점에서 해당 사업은 이와 부합하며, 특히 몽골의 도시 빈곤층, 특히 여성의 사회진출 기회 부여라는 측면에서 중요성을 가진다. 특히, 2009년 해당지역에서 이루어진 지역조사에 따르면 실업률이 $47.8 \%$ 에 이르며, 특히 2 30대 청년층의 실업률은 $49.8 \%$ 에 달하는 등 빈곤지역의 취업을 위한 단기 직업훈련의 대상자는 충분하다고 판단되었다.

사업의 단기목표와 기대효과로는 (1) 지역사회 여성가장 및 청소년 연 80여 명 직업훈련 달성, (2) 직업훈련 후 수료생의 $40 \%$ 이상 취업 및 창업, (3) 직업훈련생 중 3 개 그룹 설정, 소규모 창업 유도, (4) 아동 관리 매월 평균 40건 등을 언급하고 있으며 이는 궁극적으로 수료생의 안정적 가계 소득 확보와 이를 통한 해당 가족의 빈곤 탈출, 아동 영양, 교육, 보건 수준 향상 등을 목표로 하고 있다.

사업의 주요 부분인 직업훈련원 운영과 지역 내 창업, 취업 여건 개선 사업은 일자리 창출과 직접적인 연관성을 가진다. 그 대상은 빈곤층, 특히 많은 경우 여성으로 설정되고 있다. 일자리 자체는 양질의 일자리라고 할 수는 없으며, 일자리 창출의 방법도 단기 직업기술 전수를 통한 취업 유도와 자영업자 
육성에 두고 있다. 이는 빈곤층이 처한 경제적, 사회적 여건을 고려할 때 장기간 높은 질의 교육을 통한 전문가 양성과 이에 맞는 일자리 창출 방식은 현실적으로 한계를 가지고 있는 것에서 기인한다. 그럼에도 불구하고 해당 사업의 초기 직업훈련 부문 설정이 현지의 고용환경, 노동시장의 특성을 정확히 반영한 것인가라는 질문에 대해서는 아직까지 긍정적인 답을 기대하기는 어렵다고 보여 진다.

사업의 분석과 평가를 통해 향후 사업의 과제와 시사점을 도출해 보면 다음과 같다. 첫째, 빈곤층 여성을 대상으로 하는 보다 다양하고 고용지향적인 단기 직업훈련 부문과 프로그램 개발이 절실하다. 예를 들어 현재 체쯔 지역 내에서 운영되고 있는 복지센터(Culture \& Education Center for Welfare) 의 교육, 복지, 보건 프로그램 활성화와 이를 지역사회 일자리 창출 사업과 적극 결합, 활용하는 방안을 생각해 볼 수 있다. 둘째, 취업과 연계된 직업훈련 사업의 필요성과 효과성에 대한 보다 적극적인 홍보가 필요하다. 홍보의 부족은 사업 초기 직업훈련 신청자 수의 미달 등을 통해서도 나타난바, 이는 적절한 훈련생 선발과 빈곤층을 우선하는 사업의 취지를 달성하지 못하게 할 수 있다. 셋째, 창업·취업을 지원하는 조직의 형성과 창업의 능력 및 의지가 있는 훈련생들의 수가 충분히 조성될 수 있도록 보다 집중적인 지원을 해야 한다. 이는 교육수료생의 구직활동에 대한 정기적인 모니터링, 직업전문상담센터를 통한 정보제공, 훈련생 역량 사업 강화와 연결된다. 현재까지 체쯔 지역 창업 · 취업 지원 조직의 활성화는 그리 큰 효과를 거두지 못한 것으로 판단되는바, 이를 보완할 수 있는 방안을 모색해야 한다. 예를 들어 창업 - 취업 지원 조직과 지방정부의 관련 지원 프로그램이 효과적으로 결합되도록 유도 하거나, 교육생들의 교육 만족도 및 중간 평가 등을 통해 창업, 취업 의지를 고양시키는 방법 등도 고민해 볼 수 있다. 또한 훈련과목 선정 시 소규모 창업이 가능한 기술과목을 선정하되, 이를 위해 사전 시장조사 및 타당성 여부를 면밀히 검토해야 한다. 다섯째, 사업을 주관하는 각 기관, 파트너 간의 유기적이며 긴밀한 협조와 사업조율이 중요하다. 특히 3 개 기관이 공동으로 수행하고 있는 해당 사업은 뚜렷한 조율의 주체가 없이 각자 자기 부문의 사업에 투입되는 형식을 취하고 있는데, 이는 자칫 사업 간 유기적 연관성을 잃기 쉬우며, 병렬적인 사업의 진행으로 이어질 위험성이 존재한다.

\section{마. 사업 사례 비교 분석}

언급된 KOICA 지원 사업들을 일자리 창출 유형, 일자리의 수준, 일자리 성격, 민간기업의 역할, 향후 사업의 확장 가능성 등 몇 가지 변수에 의해 비교해 보고자 한다.

우선 일자리 창출 유형을 통해 비교해보면, 가나 현대-코이카 드림센터와 캄보디아 KOICA-UNIDO 그린 일자리 창출사업은 직접적 일자리 창출 유형에 보다 가깝다고 할 수 있으며, 모잠비크 마니싸 지역 빈곤퇴치 지원 사업과 몽골 체쯔지역 직업훈련 및 일자리 창출 사업은 그 방식과 결과의 측면에서 보다 간접적인 유형이라 할 수 있다.

일자리의 창출 방법을 보면, 현대-코이카 드림센터와 캄보디아 KOICA-UNIDO 그린 일자리 창출사업은 캄보디아 현지 고용상황을 반영한 역량개발 사업과 이를 통한 양질의 노동력 공급을 지향하며, 마니싸 지역 빈곤퇴치 지원 사업과 체쯔지역 직업훈련 및 일자리 창출 사업은 각각 장기적 혹은 단기적 기술이전을 통한 수료생들의 취업, 창업의 기회 확대를 꾀하고 있다. 즉, 전자는 양질의 인력 개발(역량개발) 사업에 강조점을 둔다면, 후자의 경우는 보다 기술이전의 강조를 통한 취업 및 
자영업의 가능성에 무게를 두고 있다. 또한 가나 드림센터와 캄보디아 그린 일자리 창출사업은 다른 두 사업에 비해 현지 고용시장의 요구를 보다 반영한 사업이라 할 수 있다.

민간기업의 역할의 측면에서 사업들을 비교해 보면, 현대-코이카 드림센터와 KOICA-UNIDO 그린 일자리 창출사업에 있어 민간 기업의 역할은 상대적으로 매우 높았다. 이는 기업의 개도국 현지의 이윤확대, 판로 확보 과정과 현지 인력 양성의 목표가 상호 잘 매칭 되고 있음을 의미한다. 특히 가나 아크라의 현대자동차 대리점과 정비소는 학생들에게 인턴십, 현장직업훈련(OJT) 기회 등을 제공함으로써 기업이 일자리 창출에 능동적인 역할을 할 환경적 가능성이 높음을 볼 수 있다. 반면 마니싸 지역 빈곤퇴치 지원 사업의 경우, 포스코의 역할이 문맹퇴치운동에 대한 재정지원, 초등학교 후원 등 제한적인 부문에만 머물고 있으며, 이는 포스코의 주력 산업부문과 해당 사업과의 내용적 연관성이 현저히 낮음에서 기인한다.

사업을 통해 창출되거나 창출될 일자리 수준을 비교하면, 가나 현대-코이카 드림센터와 캄보디아 그린 일자리 창출사업의 경우 임금, 고용조건 등의 측면에서 비교적 양호한 수준으로 기대되며, 특히 캄보디아 사례의 경우 창출되는 일자리의 성격은 보다 사회적 일자리를 지향한다. 한편 사업의 확대가능성 측면에서 보면, 가나 현대-코이카 드림센터와 캄보디아 그린 일자리 창출사업의 경우 그 가능성이 매우 높다고 판단되며, 몽골 체쯔지역 직업훈련 및 일자리 창출 사업의 경우 상대적으로 확대 가능성은 낮다고 판단된다.

향후 사업을 전개하면서 예상되는 장애요인을 살펴보면, 현대-코이카 드림센터의 경우 사업의 확대여부가 가나의 자동차 시장의 활성화 정도와 직접적으로 연관되어 있으며, 경제 위기로 인한 내수 위축 시 사업에 부정적 영향을 미칠 가능성이 있다. KOICA-UNIDO 그린 일자리 창출사업의 경우 현지 환경 관련 기업의 참여 정도가 사업의 성공과 확산 가능성에 영향을 줄 수 있다. 마니싸 지역 빈곤퇴치 지원 사업의 경우는 지역사회의 문화적 요인, 지역 공동체와의 소통의 문제, 기타 기후적 요인 등에서 영향을 받을 수 있다. 한편, 몽골 체쯔지역 직업훈련 및 일자리 창출 사업의 경우, 몽골국제대학 내 직업훈련센터(VTC)에서 수행되고 있는 위탁 직업훈련과정이 보다 전문성을 가져야 하며, 빈곤층 청장년의 취업률을 높일 수 있는 전략적 과목의 개설이 향후 사업 전개에 있어 관건이다. 또한 사업계획서에서도 명시한 바, 훈련센터 수료생, 지역 관련자, 전문가가 결합하는 취·창업 지원 조직의 활성화 여부가 중요하다. 
$<$ 표 7> 사업별 일자리 창출 관련 비교와 사업 확대 가능성

\begin{tabular}{|c|c|c|c|c|c|c|}
\hline 사업명 & $\begin{array}{l}\text { 일자리 창출 } \\
\text { 의 유형 }\end{array}$ & $\begin{array}{c}\text { 일자리 창출 } \\
\text { 방법 }\end{array}$ & $\begin{array}{l}\text { 민간 기업 } \\
\text { 역할 }\end{array}$ & $\begin{array}{c}\text { 일자리 } \\
\text { 수준(임금, } \\
\text { 안정성) }\end{array}$ & $\begin{array}{l}\text { 일자리성격 } \\
\text { (사회적 } \\
\text { 일자리 정도) }\end{array}$ & $\begin{array}{c}\text { 사업 확대 } \\
\text { 가능성 }\end{array}$ \\
\hline $\begin{array}{c}\text { 가나 현대- } \\
\text { 코이카 드림센터 }\end{array}$ & 직접적 & $\begin{array}{l}\text { 역량개발/ } \\
\text { 공급(고용 } \\
\text { 상황반영) }\end{array}$ & $\begin{array}{c}\text { 높음 } \\
\text { (현대자동차) }\end{array}$ & $\begin{array}{l}\text { 비교적 } \\
\text { 높음 }\end{array}$ & 높음 & 높음 \\
\hline $\begin{array}{c}\text { 모잠비크 마니싸 } \\
\text { 지역 빈곤퇴치 } \\
\text { 지원 사업 }\end{array}$ & 간접적 & $\begin{array}{l}\text { 중장기적 } \\
\text { 기술이전 }\end{array}$ & $\begin{array}{l}\text { 낮음 } \\
\text { (포스코) }\end{array}$ & 낮음 & 보통 & 보통 \\
\hline $\begin{array}{c}\text { 몽골 체쯔지역 } \\
\text { 직업훈련 및 } \\
\text { 일자리 창출 사업 }\end{array}$ & 간접적 & $\begin{array}{l}\text { 단기적 } \\
\text { 기술이전 }\end{array}$ & 없음 & 낮음 & 낮음 & 낮음 \\
\hline $\begin{array}{c}\text { 캄보디아 } \\
\text { KOICA-UNIDO } \\
\text { 그린 일자리 } \\
\text { 창출사업 }\end{array}$ & 직접적 & $\begin{array}{l}\text { 역량개발/ } \\
\text { 공급(고용 } \\
\text { 상황반영) }\end{array}$ & $\begin{array}{c}\text { 높음 } \\
\text { (삼성전자) }\end{array}$ & $\begin{array}{l}\text { 비교적 } \\
\text { 높음 }\end{array}$ & 높음 & 높음 \\
\hline
\end{tabular}

출처: 김성규, 2013a: 135

이상의 사례 비교를 바탕으로 일자리 창출의 방향성과 관련 사업의 효과성, 지속성 측면에서 몇 가지 시사점을 언급해 보면 다음과 같다. 첫째, 단순 기술이전을 통한 취업, 창업가능성의 확대보다는 고용시장 상황이 반영된 역량개발을 통한 양질의 노동력 공급, 이를 통한 일자리 창출이 보다 사업의 지속성과 효과성을 가질 수 있다고 판단된다. 이러한 전략은 산업구조와 산업화 정도 등에 따라 국가별로 차이를 보일 수 있으나, 사례에서 보여 지는 바, 가나와 캄보디아 사례의 경우 일정정도 타당성을 지닌다고 판단된다. 둘째, 개도국 현지 일자리 창출과정에는 민간기업의 능동적 결합과 역할이 중요하며, 민간기업의 개입은 사업의 초기 형성과정에서부터 사후 모니터링, 관리까지 지속적으로 이루어 져야 한다. 또한 사업의 효과성과 지속성을 위해서는 민간 기업이 사회적 책임을 가지고 기업의 이윤창출과도 부합되는 중장기적 투자를 확대하고 해당 정부는 이에 부합하는 정책적 지원을 하는 구조가 필요하다. 이러한 맥락에서 기업의 개도국 현지 진출을 위한 사전 기업 이미지 제고 (image promotion)와 홍보 차원의 사업 지원은 지속가능성 측면에서 늘 한계를 지닐 수밖에 없다.

\section{IV . 사업 사례의 유형별 평가}

이번 장에서는 일자리 창출의 유형별, 즉 간접일자리 창출과 직접 일자리 창출 유형에 따른 평가와 시사점을 정리해 보고자 한다. 우선 간접 일자리 창출 사업 분석을 통한 평가와 시사점은 다음과 같이 요약될 수 있다. 
첫째, 노동시장 연계형 직업교육훈련은 해당 국가의 직업훈련정책을 뒷받침할 수 있는 방향성을 가지고 있어야 한다. 예를 들어 베트남의 경우 관련 국가 정책인 'National qualifications framework(NQF)' 와 'National vocational qualifications framework(2011 2020, NVQF)'의 실행을 지원할 수 있는 프로그램이어야 한다. 이 프로그램은 실용적인 기술 숙련, 지역 간 (숙련)인력 불균형 해소, 세계무대에서 보다 높은 경쟁력 제고를 지향하고 있다.

둘째, 노동시장 연계형 직업교육훈련 시스템 구축 과정에 기업의 참여를 강화할 수 있는 메커니즘을 설정해야 한다. 기업은 노동시장, 기업 요구 관련 정보를 공개하고, 훈련과정개발, 커리큘럼 개발, 교수법, 학습효과에 대한 검증 및 평가 방법 개발에 참여해야 한다. 프로그램 실행 이후 기업의 요구에 맞게 훈련되었는지에 대한 평가와 그 결과를 아울러 공개해야 한다. 또한 이를 위해 기업과 직업교육훈련 기관과의 상호 계약관계 형성이 필요하다. 계약관계를 통해 기업에게 보다 큰 이니셔티브를 부여할 수 있으며, 예를 들어 직업훈련 교사에게 기업 현장 실습(field work) 기회, 새로운 장비와 신기술 관련 교육을 받을 수 있는 기회 등의 제공도 가능하다. 더 나아가 기업은 우수 훈련생들을 직접 채용하는 사회적 책임을 수행할 수 있다. 결국 이는 기업과 현재 노동시장의 요구에 맞는 기술 전수, 기술 표준과 자격 평가(assessment) 제도 구축, 그리고 일자리 창출을 동시에 가능하게 하는 메커니즘의 구축을 의미한다.

셋째, 직업교육훈련 기관에게 보다 큰 자율성과 동기부여를 해야 한다. 즉, 노동시장의 요구를 반영하되, 기관에게 능력에 맞는 훈련 프로그램, 훈련의 범위와 규모 등을 스스로 설정할 수 있는 권한을 부여해야 한다. 또한 훈련기관은 훈련생, 기업을 중심으로 접근하여 훈련 기법 개발에 힘써야 하며, 훈련 프로그램과 기법의 도입, 개발 측면에서 해당 선진 공여국의 경험과 노하우 전수를 적극 요청, 활용할 수 있어야 한다.

넷째, 노동시장 연계형 직업교육훈련은 인력이 노동시장에 효과적으로 편입되기 위한 현장 학습 (workplace learning), OJT(On the Job Training) 등을 포함한다. 이러한 과정의 활성화를 위해 해당 과정 이수에 대한 자격증을 부여하는 방법을 적극 모색해 볼 수 있다. 예를 들어 기업은 사회적 책임을 수행하는 의미에서 OJT 프로그램을 강화하는 한편 기업이 보다 양질의 인력을 스스로 확보하기 위한 '기업 내 직업훈련 기회'로 이를 활용할 수 있다. 즉, 기업의 사회적 책임 측면에서의 '비구속성 OJT 프로그램 확대'와 기업을 위한 양질의 인력 양성을 위한 '사내 직업훈련 프로그램의 활성화'가 이루어 질 수 있다.

다섯째, 노동시장의 숙련인력 요구에 부응하기 위해서는 적정한 국가 직업기술 표준과 직무능력표준 (competency standards)을 만드는 것이 필요하다. 예를 들어 첨단 기업 수준에 맞는 직업기술 표준을 마련하고 이에 조응하는 임금, 노동보험 설정, 훈련 방식의 구체화, 정교화 작업이 요구된다. 이는 양질의 일자리 창출의 방향과도 그 맥을 같이 한다. 이를 위해 국가 표준기술 평가규준과 직업기술의 자격부여 권한을 가진 '산업기술 위원회(Industry Skills Council)'의 구성도 고려해 볼 수 있다.

여섯째, 직업교육훈련의 효과성을 높이고 정책 결정과 직업교육 관련 효과적 전략수립을 위해서는 훈련의 질적 관리, 경제상황과 산업구조 분석, 노동시장 분석, 직업 문화와 직업훈련 과정에서의 
소통 분석 등 다양하고도 광범위한 분석 노하우와 관련 통계적인 데이터베이스 구축이 중요하다. 직업교육훈련 경험의 축적과 축적된 통계 데이터는 직업훈련의 구조, 분야 그리고 비용 등을 설정, 판단하는데 중요한 정보를 제공하며, 교사, 훈련생, 기업가, 취업 노동자에게 직업훈련의 질적 향상을 위한 지표와 규준 제공을 가능하게 한다.

일곱째, 직업교육훈련 시스템의 혁신과 새로운 모델 제시를 위한 국제적 협력이 보다 강화되어야 한다. 현재는 직업훈련생, 교수 그리고 기관 운영자 간의 국제적인 통합, 소통 능력이 강조되는 상황이다. 국제적 협력을 위해서는 언어, 특히 영어와 IT 훈련 등 이에 부합하는 프로그램, 커리큘럼 설정도 아울러 필요하다. 또한 이를 위해 일본, 한국, 영국, 독일 등 직업훈련 선진국의 관련 기관과 $\mathrm{ADB}$, World Bank, UNDP, ILO 등 국제기구로 부터 기관 경영 노하우 학습 등 공조, 협력이 필요하다.

다음으로 직접 일자리 창출 사업 분석을 통한 평가와 시사점은 다음과 같이 요약될 수 있으며, 이는 특히 사업 설계, 사업 실행, 사업 내용 등의 측면에서 정리되었다.

첫째, 사업설계는 정확하고도 보다 정교한 대상 설정(targeting)에서 출발해야 하며, 선정된 대상을 위한 맞춤형 지원 프로그램이 필요하다. 이는 실질적인 사업목표에 도달할 수 있는 전략과 로드맵 작성을 가능하게 한다. 예를 들어 몽골 빈민지역 대상 직업훈련의 경우, 경제적 안정을 위한 최소한의 일자리가 절대적으로 필요한 여성을 대상으로 하는 이른바 ‘고용 지향적 단기 직업훈련 프로그램'의 개발이 절실하다. 현재 여성들의 이·미용 부문 직업훈련과 취업알선은 비교적 효과적으로 이루어지고 있으나, 이는 시장의 한계로 인해 다른 대안의 모색이 필요한 상황이다. 예를 들어 사업의 지속성을 위해 현재 체쯔 지역 내에서 운영되고 있는 복지센터의 교육, 복지, 보건 관련 프로그램의 활성화와 이를 통한 지역사회 일자리 창출 방안을 적극적으로 고려해볼 필요가 있다. 또한 사업 설계 시 빈곤층 대상 설정을 보다 정교화 해야 할 필요성이 제기되는데, 예를 들어 가나 현대-코이카 드림센터의 경우 빈곤층 무상 교육 대상 장학생 선발을 위한 객관적인 지표 마련과 심사 과정을 좀 더 합리적으로 개선해야할 필요성이 있다.

둘째, 사업 실행에 있어, 공여국과 수원국의 수행기관 뿐만 아니라 관련된 주체들 간의 네트워킹과 합리적 역할 분담이 필요하다. 여기에는 해당 국가 정부부처의 전략적 지원과 사업 실행 시 주변자원 활용의 개념까지 포괄될 수 있다. 현대-코이카 드림센터의 사례는 재학생, 졸업생 및 교사 등 기술학교의 수혜자들과 가나 아크라 자동차 대리점과 정비소, 플랜 가나 등 사업주체간 네트워크 형성의 중요성을 잘 보여주고 있다. 또한 이러한 네트워킹은 사업 수행 시 발생할 수 있는 여러 문제에 대한 신속하고도 전문적인 대응을 가능하게 한다는 점에서도 중요하다. 한편 사업지와 주변 공동체와의 의사소통과 이를 통한 네트워크 또한 중요하다. 모잠비크 마니싸 농업훈련원 사례의 경우, 사업의 효과성과 지속성을 위해 지역주민 참여는 절대적이며, 아프리카 지역의 경우 지역사회에 이미 형성되어 있는 문화적 폐쇄성, 배타성 등 사회적 특수성을 극복하기 위해서 이러한 의사소통 구조의 형성은 중요하다. 네트워크의 활성화는 사업실행의 전문성과 투명성을 높일 수 있는데, 이는 사업 현장에서 사업을 수행하고 있는 현지 NGO 등의 보다 체계적이고 투명한 운영원칙 수립에도 긍정적인 영향을 미칠 수 있다. 예를 들어 마니싸 농촌 훈련원의 경우, 중요하게 추진되고 있는 공동농장 운영 관련 행정, 
농작물 판매, 수익관리 등 전반적 운영 규약과 지침 등을 문서로 수립하게 하는 것을 가능하게 할 수 있다. 특히 사업의 조율의 주체가 없이 기존 현지 기관에 위탁을 하는 형식의 사업은 공여국 수행기관의 이니셔티브 상실, 실행 사업 간의 유기적 연관성 저해, 단순 병렬적인 사업의 진행으로 이어질 위험성이 존재한다. 반면 UNIDO-KOICA-SAMSUNG의 캄보디아 전기전자 폐기물 관리 및 그린 일자리 창출 지원 사업은 공여기관 주체 뿐 만 아니라 국립기술훈련원(NTTI), 관련 정부부처들과의 네트워크가 비교적 잘 작동되고 있는 사례라 할 수 있다.

셋째, 사업 내용의 측면에서 보면, 개도국에서 새로운 일자리 창출을 지향하고 있는 기술교육 프로그램은 현장 활용성과 중장기적 고급 인력 양성의 측면에서 전문성을 갖춰야 한다. 또한 해당 교육 프로그램은 관련 민간기업, 교육기관, 연구소 등 다양한 기관의 지원을 통해 상시 업데이트될 수 있어야 한다. 전문성의 확보를 위해서는 훈련과목 선정 시 명시적으로 취업과 창업의 가능성을 염두에 두고 교육 과목과 프로그램을 설정 하되, 이를 위해 인력 수급현황 등 사전 노동시장조사 및 교육의 타당성 여부를 면밀히 검토해야 한다. 사업의 진행과 함께 교육 프로그램의 상시적 모니터링, 교육 내용의 지속적인 업데이트는 프로그램의 차별성을 높이고 사업의 효과성을 높이는데 중요한 요인이다. 여기에 수준 있는 교사의 안정적 확보와 공급 또한 중요하게 고려해야 될 사항이다. 예를 들어 캄보디아 전기전자폐기물 관리 및 그린 일자리 창출 사업의 경우 업데이트 된 기술의 지속적 공급은 사업의 효과성 확보와 지속가능한 성공에 관건이 되는 요인이다. 이는 사업에 참여하고 있는 민간기업의 능동적이고도 지속적인 정비 관련 노하우와 기술 전수, 양질의 교육 인력 공급으로 가능하다. 한편, 교육을 받는 훈련생들의 학습동기를 고취할 수 있는 장치 또한 프로그램에서 중요하다. 이를 위해서 학습 결과에 따른 인센티브 부여뿐만 아니라 교육 시작 시 수강생들의 욕구조사 등을 통해 수업 운영을 기획하는 것도 하나의 방법이다. 또한 일부 사업 사례에서도 확인되었듯이, 교육과정에는 기술 이전, 실습 등의 내용 외 인간관계형성과 인성 교육 강화 관련 프로그램이 포함되어야 한다. 이를 통한 소양의 습득은 수료생의 이후 직업 활동 시 유용한 자산이 될 수 있다.

넷째, 사업 수행 시 해당 지역사회의 원로, 관련 연구기관, 학교 등 이른바 ‘주변 자원’의 활용 노하우를 축적해 나가야 한다. 우선 현지에서 검증된 $\mathrm{NGO}$ 등의 조직을 활용하여 사업의 의미와 중요성을 상시적으로 홍보하고, 동시에 주변의 연관 기관이나 단체와 자매결연 등을 통한 협력 사업을 확대해 나가야 한다. 예를 들어 가나 현대-코이카 드림센터 사업지인 코포리두아(Koforidua) 지역에 소재한 기술 전문대학인 K-Poly(Koforidua Polytechnic)와의 협약을 통해 드림 센터의 교육 과정과 내용을 지속적으로 모니터링하려 한 시도는 하나의 좋은 사례 이며, 이는 드림센터 졸업생의 해당 대학 진학 프로그램을 마련하는 계기로 작용할 수 있다. 또한 모잠비크 현지 농업훈련원이 현지 농업 교육기관 (CEFATE), 가나안 농군학교 등과 협력하여 훈련원 운영의 안정을 도모한 것도 같은 맥락에서 의미 있는 사례이다. 따라서 사업 지역의 설정 시 주변 자원 활용의 가능성에 대한 사전 점검이 필요하며, 이를 바탕으로 사업의 확대 방안과 가능성을 사업 형성 시 사전에 미리 구상해 보는 것이 중요하다.

다섯째, 일자리 창출 사업은 그 성격상 역량 있는 민간 기업의 적극적 참여와 역할이 매우 중요하며, 따라서 개발협력의 관점에서 이를 이끌어 낼 수 있는 노하우 개발이 필요 하다. 민간 기업의 적극적 결합은 재정지원, 기술력, 운영 노하우와 능력 등 민간 기업이 가지고 있는 장점의 활용과 더 나아가 
실질적인 일자리 창출로 연결될 가능성이 높다는 점에서 긍정적이며 의미가 있다. 예를 들어 현재 캄보디아 현지에서 요구되고 있는 전기전자 전문가 및 일반 정비사 양성 교육의 규모 확대 요구는 민간기업의 이해관계와 조응할 때 그 가능성이 높아 질 수 있다. 교육과정 규모의 확대 요구와 더불어 캄보디아 사회 취약계층을 해당 교육 과정에 보다 적극적으로 결합시켜야 한다는 요구와 이를 위한 현실적 방안 모색이 존재한다. 국가의 정책적 의지와 더불어 이를 위한 재원의 마련 등은 기업의 사회적 책임(CSR) 영역에서 제안될 수 있다. 한편 공여국 민간기업 외 환경사업과 연관된 캄보디아 현지 민간기업의 발굴과 이들과의 파트너십 확대가 아울러 중요하다. 이를 위해 사업 수행 주체는 민간기업 관계자들에게 전기전자 폐기물 관리의 중요성과 사업의 취지를 설득하고 이를 사업에 반영하도록 하는 동기부여 프로세스를 개발해야 한다.

\section{V. 정책제언 및 시사점}

이번 장에서는 해당 사업사례 분석을 통해 지향점 도출과 향후 사업을 위한 정책제언을 하고자 한다. 우선 개도국 일자리 창출 사업의 지향점에 대해서 정리해 보고자 한다.

첫째, 일자리는 사회적 일자리를 지향해야 한다는 점이다. 개발협력 과정에서의 사회적 일자리는, (1) 일자리 창출의 목적이 빈곤층 등 사회배제집단의 노동시장 편입을 목적으로 하며, (2) 일자리의 창출 방식을 보면 국가와 시장에 의한 것뿐만 아니라 비영리민간단체, 시민사회, 공동체 성원의 자발적 참여를 중시하는 특징을 보이며, (3) 창출된 일자리는 개인의 경제활동과 소득 향상 뿐 만 아니라 해당 지역사회의 삶의 질 향상과 공동체의 연대· 통합에 기여하는 일자리라고 정의내릴 수 있다.

이러한 맥락에서 개도국에서 사회적 일자리 창출의 필요성과 그 의미에 대해서 정리해 볼 필요가 있다. 사회적 일자리는 무엇보다도 '개도국 빈곤층은 그에 적합한 일자리를 가져야만 한다'라는 절박성에 부합한다. 취약계층과 빈곤층에게 일자리가 없다는 것은 당면한 경제적 빈곤 이외에 정상적인 사회생활에 필요한 사회, 문화적 자원에서 구조적으로 소외되고 배제된 상태의 지속을 의미하기 때문이다. 따라서 취약, 빈곤 계층에게 일자리는 자활, 자립의 수단이며, 또한 그 일자리는 지역 사회 서비스나 자활 공동체 운영 관련 일자리 등 사회적 일자리로 연결됨이 바람직하다. 개도국은 경제적, 인구학적 특징에 의해 사회 서비스의 욕구가 날로 증대하고 있으며, 사회적 일자리 창출의 모델은 이를 충족시킬 여지가 크다는 점도 주목될 수 있다. 따라서 이러한 욕구가 국가의 노동시장, 고용 전략 형성에 중요하게 반영되어야 한다. 또한 인구의 노령화, 전통 가족의 해체, 여성의 사회적 역할의 변화 등 사회·인구학적 변화는 전통적으로 가족의 영역에서 제공되던 사회서비스의 사회화 필요성을 높이고 있다. 선진국에서는 이미 이러한 사회 서비스가 시장의 영역에서 혹은 공적 영역에서 복지 서비스 (상품)의 형태로 제공되고 있다. 마지막으로 포용성의 측면에서 일자리의 제공, 특히 사회적 일자리는 개도국 취약 빈곤층의 경제활동참여를 통한 재 빈곤화 방지 등 사회적 기회 및 안전망의 역할을 훌륭히 
수행한다는 점이다. 더 나아가 이는 단기적인 고용창출의 효과를 넘어 사회 서비스의 부가가치 창출로 이어질 수 있으며, 국가의 성장 잠재력에도 기여하게 되는 선순환 구조형성에 기여 한다. ${ }^{4}$

둘째, 개발협력과정에서의 일자리 창출은 고용안정성 보장을 중심으로 하는 괜찮은 일자리(decent work)를 지향해야 한다. ILO는 1999년 제 87차 국제노동회의(The 87th Session of the International Labour Conference)에서 decent work를 '자유, 공평, 안전 그리고 인간 존엄성이 존중되는 조건하에 남녀 모두에게 괜찮고 생산적인 일자리를 얻기 위한 기회'로 정의했다. 즉, decent work는 특정 부문의 직업이나 직업의 경제적 사회적 보상 조건을 언급하는 용어, 예를 들어, 좋은 혹은 나쁜 일자리(good job or bad job)가 아닌, 사회적 기회(social opportunities)의 측면에서 이해되고 있으며, 따라서 보다 '가치론적'인 개념이라 할 수 있다.5) 특히 이 요소들은 개도국에서 창출되는 사회적 일자리의 질을 판단하는 기준으로 유용할 수 있다. 즉 개도국 사회적 일자리의 가치를 설정하는 데는 좋은 일자리(good job)의 개념보다는 decent work의 개념이 보다 적합할 수 있다. 또한 좋은 일자리, 만족스런 일자리의 기준은 대개 주관적인 판단, 경제적인 보상 등으로 측정되며, 이는 개도국에서 만들어지는 일자리의 질을 측정하는 데는 일정정도 한계를 지닌다. 좋은 일자리는 임금과 부가급여와 같은 노동에 대한 경제적 보상과 사회적 지위 등에 집중하는 반면, decent work는 노동에 대한 보상 뿐 아니라 사회보호 등을 포함한 보다 포괄적인 접근이라는 점, 최저임금이나 탈 빈곤 가능성 등과 관련하여 노동시장에서 불리한 위치에 있는 인구 집단, 즉 여성이나 고령자, 장애인 등이 일자리를 얻고, 일자리를 통해 적절한 삶의 수준을 유지할 수 있는가를 판단하는데 유용하다(김보람 외 2012: 9).

셋째, 일자리 창출 지원 전략 측면에서 중장기교육을 통한 양질의 일자리 창출과 다수의 실업자 층과 소외계층을 대상으로 하는 단기 기술 전수, 이를 통한 양적인 일자리 창출 추구라는 '양면 전략'이 개도국 내 사회경제적 상황에서 매우 유용함을 알 수 있다. 즉, 개도국 내 사회경제적 배경, 지역적 특수성 등을 고려하여 단기 기술 이전을 통한 취업 유도와 중장기 고급직업훈련교육에 대한 투자를 통한 양질의 일자리 창출 전략을 구사할 수 있다. 그런데 이러한 전략 형성, 지원을 위해서는 개도국 내 노동시장 분석이 매우 중요하며, 이는 다른 사회, 경제, 문화적 분석보다도 선행되어야 한다. 즉, 해당 국가의 노동시장 특성, 인력 수급 관계, 산업 구조와 유망 산업 부문 등을 파악하는 것은 새로운 직업훈련교육의 방향성을 설정하는데 중요한 단서를 제공할 수 있다. 결국 ‘노동시장 연계형' 직업교육훈련 시스템 ('labour market oriented' vocational education and training system)이 요구되고 있으며, 이는 무엇보다 지금까지의 해당 개도국의 공교육과 직업교육훈련이 노동시장과 기업의 욕구에 효과적으로 조응하고 있지 못했다는 판단에서 기인한다. 현재 ILO에서 시범사업으로 수행 중인 '노동시장 연계형 직업훈련 사업‘ 결과는 향후 개도국 청년고용 활성화정책과 직업교육훈련 사업 지원 ODA의 방향성을

4) 사회적 일자리의 성격, 이에 따른 사업조직 유형과 사업 내용을 분류할 수 있다. 즉, (1) 복지서비스(사회보호 서비스) 제공형, (2) 노동시장 활성화형, (3) 친환경적, (4) 자본 지원형, (5) 농촌형 등으로 분류할 수 있다. 조직유형을 보면, 커뮤니티 비즈니스, 공동농장, 협동조합, 사회적 기업 등의 형태를 띤다. 사업 내용은, 사회복지 제공사업 에서부터 농작물 품종개량, 마이크로 금융 사업까지 다양하다.

5) ILO가 decent work의 중요 요소로 (1) 노동기회(opportunity for work) (2) 고용선택의 자유(work in conditions of freedom) (3) 생산적인 노동(productive work) (4) 노동에서의 평등(equity in work) (5) 고용안전(security at work) (6) 노동에서의 인간 존엄성(dignity at work) 등을 명시하고 있는 것도 같은 맥락에서 이해될 수 있다. 
모색하는 데 일조할 수 있으며, 향후 간접적 일자리 창출과 관련된 $\mathrm{KOICA}$ 의 사업 형성, 지원에도 시사점을 제공 할 수 있다.

넷째, 일자리 창출 사업에 민간 기업이 적극 결합될 수 있는 구조를 마련해야 한다. 민간 기업의 적극적 결합은 재정지원, 기술력, 운영 노하우와 능력 등 민간 기업이 가지고 있는 장점이 활용될 수 있다는 의미와 더 나아가 실질적인 일자리 창출로 연결될 가능성이 높다는 점에서 긍정적이며 의미가 있다. 물론 이러한 결합은 민간 기업의 현지 기업 비전과 이윤확보에도 도움을 주는 방향이어야 하며, 민간기업의 주력 업종과 결합된 개발협력사업의 형성이 개도국 내 일자리 창출과 기업의 관심사를 동시에 충족시킬 수 있는 전제가 될 수 있다. 


\section{<참고문헌>}

\section{- 국내문헌}

강혜영(2008), 최근 베트남의 노동환경 및 인적자원관리(HRM) 변화와 베트남 기업

사례연구, 국제노동브리프, Vol. 6, no. 10,pp.17 29, 한국노동연구원

김보람, 문은하, 이승윤(2012), 퍼지셋 방법론(Fuzzy-set ideal type approach)을 활용한 사회적 기업 일자리 질 분석: ILO의 '괜찮은 일자리(decent work)'정의를 중심으로, 2012년 춘계학술대회 발표논문, 사회복지정책학회.

김성규(2014), 기업의 글로벌 CSR 현황과 공유가치창출(CSV),국제개발협력』No.1, KOICA

김성규(2013a), 개도국 일자리 창출 사업 지원 방안 연구, KOICA

김성규(2013b), 개도국 청년고용정책과 ODA: ‘노동시장 연계형' 직업교육훈련 시스템 형성 논의를 중심으로, $\mathrm{KOICA}$

김성규(2012a), 기업의 글로벌 사회적 책임(Global CSR)과 개발협력,『국제개발협력』No.1,

KOICA

김성규(2012b), 사회적 기회와 안전망 확대를 위한 개발협력 방안, KOICA

김성규(2012c), 개도국 민간부문 활성화 ODA 방안: 빈곤층 친화적 시장개발(MM4P)사업을 중심으로, $\mathrm{KOICA}$

김성규(2011), 사회적 기업 연구동향과 주요 이슈,사회적 기업과 인적자원전략』, KLI

연구보고서, 한국노동연구원.

김종법(2009), 유럽의 사회적 기업: 성과와 한계, 세계지역연구논총, 28집, 1 호.

김순양(2010), 사회적 기업에 대한 효율적인 정부지원시스템 구축방안: 정부지원을 위한

기준 설정 및 행정체계 확립을 중심으로, 한국사회정책, 제 17 집, 제 2 호.

김승택(2010), 녹색성장을 통한 일자리 창출 연구, 경제 · 인문사회연구회 미래사회협동연구

총서, 기후변화 대응·녹색성장 종합연구, 한국노동연구원.

박수지(2010), 사회적 취약계층 대상 일자리창출사업의 유형화, 사회복지정책 Vol. 37. No.

2, pp51 72. 
안혜원, 이민규(2010), 지역활성화를 위한 커뮤니티 비즈니스 도입방안, 한국행정학회, 한국행정학회 하계학술발표논문집.

오성욱 외(2013), Knowledge Sharing Program, 2012 경제발전경험 모듈화사업: 국가 인적자원의 효율적 활용을 위한 고용서비스 제도 구축, 고용노동부, 한국고용정보원 유재원, 박성훈 외(2010), ASEAN 후발 3개국(베트남, 미얀마, 캄보디아)의 사회경제 개발역량 제고에 관한 기초연구, 대외경제정책연구소

윤정향(2007), 사회적일자리 창출 사업 실태와 개선방안, 한국고용정보원.

응엔민프엉융(2011), 베트남의 지속가능한 관광개발정책에 관한 연구, The Policies for

Sustainable Tourism Development of Vietnam, 학위논문(석사), 대구대학교 이영현(2013), 직업훈련 프로그램 종합평가 보고서: 베트남 사례를 중심으로, KOICA 이은영(2011), 기업의 사회적 책임활동(Coporate Social Responsibilty; CSR)이 기업의 브랜드 자산에 미치는 영향에 관한 연구, 한국항공경영학회지, 제9권 2호.

이재영, 제성훈 외(2012), 몽골의 투자환경과 한국기업의 진출 확대 방안, 대외경제정책연구원. 이종서(2010), 유럽연합과 기업의 사회적 책임(CSR): 현황과 전망, 국제지역연구 제 14 권, 제 1 호.

이홍식, 김형주(2010), 아세안 주요 2개국(베트남, 인니)의 노동시장 현황과 변화전망, 대외경제정책연구소

임영석 외(2013), 중소기업의 베트남시장 개척방안 연구, 한국수출입은행, 해외경제연구소 장근섭(2007), 2007년 베트남 노동시장 및 노사관계 전망, 국제노동브리프, Vol. 5, No. 2, pp.48 58, 한국노동연구원

전병유 외(2003), 사회적 일자리 창출방안 연구, 노동부 학술용역사업, KLI 연구보고서, 한국노동연구원.

정대용 - 김민석(2010), 조직구성원의 사회적 가치추구와 경제적 가치추구가 사회적 기업의 발전에 미치는 영향에 관한 연구, 산업경제연구, 제 23 권 제 5 호.

정영순 - 송영경(2010), 노동통합 사회적기업 발전 방안 연구: 영국과 한국의 비교분석, 사회보장연구, 제 26 권, 제 4 호.

정재완, 김동현 외(2007), 베트남의 주요산업: 자동차 이동통신, 부동산 - 건설, 금융, 대외 경제정책연구원, KOTRA 
정재완, 이재호 외(2011), 베트남의 주요산업: 유통, 석유화학, 수송인프라건설, 대외경제 정책연구원, KOTRA

조상미 · 김진숙 · 강철희(2011), 사회적 기업 정책 특성 비교 분석 연구: 영국, 프랑스, 이탈리아, 한국을 중심으로, 사회복지정책, Vol. 38, No.2.

조정윤 외(2009), 한국직업교육훈련의 해외진출을 위한 직업교육훈련협력 연구: 한국 직업 교육훈련 발전경험의 대 베트남 적용 가능성 연구, 한국직업능력개발원, 교육과학 기술부

주성수, 김성현(2014), 글로벌 CSR의 개발협력 현황과 발전과제: 국내외 사례 비교분석, KOICA

채종헌 · 이종한(2009), 지속가능발전을 위한 사회적 기업의 역할과 활성화방안에 관한 연구,

한국행정연구원.

채종헌 - 최준규(2010), 한국 사회적 기업의 운영상 특성과 법 제도 인식에 관한 연구, 도시행정학보, 제23집 제2호, KIPA 연구보고서 2009-26, 한국도시행정학회.

최민경(2008), 국제개발원조와 민관협력: 선진공여국의 PPP사례와 한국형 Model, KIEP 발표문.

최영렬 외(2009), 한국직업교육훈련의 해외진출을 위한 직업교육훈련협력 연구: 한국형 직업교육훈련 개발협력 모델 구축연구, 한국직업능력개발원, 교육과학기술부 최영렬 외(2008), 아 · 태지역 직업교육훈련 실태조사 및 직업교육훈련 Workshop(II):

베트남, 한국직업능력개발원

포르데 아담(2007), 베트남 노동시장의 변화, 국제노동브리프, Vol. 5, No. 1, pp.13 21, 한국노동연구원

\section{- 국외문헌}

Anh, Dang Nguyen, Duong, Lebach \& Van Hai Nguyen(2005), Youth employment in Viet Nam: Characteristics, determinants and policy responses, Employment Strategy Papers, Employment Strategy Department of Vietnam.

Anh, Danh Dang(2010), Carrer Orientation Education in Vietnam, Vietnam Culture and Information Publishing House. 
Anker et al(2002), Measuring Decent Work with Statistical Indicators, ILO

Alter, K.(2004), Social Enterprise Typology, Virtue Ventures, Seattle.

Borzaga, C. \& Defourny, J.(2004), The Emergence of Social Enterprise: Routledge Studies in the Management of Voluntary and Non-Profit Organizations, Routledge.

Bhattacharya, C.B.,(2008), 'Using Corporate Social Responsibility to Win the War for Talent', MIT Sloan Management Review, vol.49, no.2.

Brown, T.J. and Dacin(1997), P.A., 'The company and the product: corporate associations and consumer product responses', Journal of Marketing, vol. 61, no.1.

Bhattacharya, C.B.,(2008), 'Using Corporate Social Responsibility to Win the War for Talent', MIT Sloan Management Review, vol.49, no.2.

Borzaga, Carlo and Galera, Giulia ed.(2008), Social Enterprise: A new model for poverty reduction and employment generation: An examination of the concept and practice in Europe and the Commonwealth of Independent States, UNDP.

Cross, R., Laseter, T., Parker, A., and Velasquez, C.(2006), Using Social Network Analysis to Improve Communities of Practice, California Management Review, University of California Berkeley, 49(1).

Defourny, J.(2001), 'Introduction: Form third sector to social enterprise', in Borzaga, C. \& Defourny, J.(Eds), in “The Emergence of Social Enterprise”, Routledge.

Dung, Nguyen Tien(2011), Vocational training for rural laborers: linking training with demand of labor market, journal of Economics and Forecasting.

Dung, Nguyen Tien(2007), Accession to WTO and its impacts on Vietnamese labor market, Journal of Economics and Forecasting.

GIZ(2009), Nationale Beschaeftigungsstrategien-der Weg zu mehr Beschaeftigung in Entwicklungs-und Transformationslaender?, GIZ

und BMZ

GTZ(2009), Cooperate Social Responsibility in Sub-Saharan Africa: A Survey on promoting and hindering factors, GTZ \& BMZ

Herzig, Guenter(2006), 'Wettbewerbs-beihilfen-und vergaberechtliche Fragen von Non-Profitorganisationen', in St.udiengesellschaft fuer Wirtschaft und Recht (ed), 
Das Recht der Non-Profit-Organisationen, Viennna, Linde.

ILO(2013), Concept Note, Geneva.

ILO(2012a), Post 2015 Development Agenda, Beyond the MDGs: It's all about jobs and livelihoods, News 8. Nov. 2012, Geneva.

ILO(2012b), Decent Work Indicators: Concepts and definitions, ILO Manual, First version, Geneva.

ILO(2011), Promoting Decent Work in a Green Economy, ILO Background Note to towards a Green Economy, The ILO Green Jobs Team.

Kawkwani, Nanak and Pernia, Ernesto M.(2000), What is Pro-Poor

Growth?, Asian Development Review, vol. 18, no. 1., ADB.

Keivani, Ramin(2010), Green Jobs Creation Through Sustainable Refurbishment in the Developing Countries, ILO.

Korachun, D., Bhattacharya, C. B. and Swain, S.,(2011), 'When and How Does Corproate Social Responsibility Encourage Customer Orientation?', Working Paper.

Laville, Jean-Louis(2011), What is the third sector? From the Non-Profit Sector to the social and solidarity economy: Theoretical debate and european reality, EMES.

Maclean, Rupert \& Wilson, David(Eds.), 2009, International Handbook o Education for the Changing World of Work-Bridging Academic and Vocational Learning, Vol. 1 6, Springer Science+Business Media B. V.

MOLISA(2010), Employment Trends in Vietnam, Employment Department.

MOLISA(2009), Report on Vocational Training in Vocational Institutions Owned by Enterprises in 2009, National Conference on Vocational Training Development for Enterprise, Hanoi.

National Statistical Office of Mongolia(2008), Mongolian Statistical Yearbook 2008

OECD(2007), Promoting Pro-Poor Growth: Policy and Guidance for Donors, DAC Guidelines and Reference Series, Paris, OECD. 
Pava, MI., Krausz, J.,(1996), 'Corporate Social Responsibility and Financial Performance: the paradox of social cost', Westport, Quorum Books.

Poter, Michael E. and Kramer, Mark R.(2006),'Strategy \& Society: The Link Between Competitive Advantage and Corporate Social Responsibility', Harvard Business Review, vol.84, no.12.

Sharpen, Clare(2006), 'Social Enterprise under the microscope: Comparing and contrasting Green-Works and Reboot', in Social Enterprise Journal Vol.2 no.1, 2006.

SIDA(2003), Malonda-The Private Sector support related to agriculture in Nissa, Stockholm: SIDA

Stanwick, P. A. and Stanwick, S. D., (1998), 'The relationship between corporate social performance and organizational size financial performance and environmental performance: an empirical examination', Journal of Business Ethics, vol. 17.

Tien Mac(2011), How the Vietnamese Find Jobs, Discussion Paper, Research Institute of Vocational Science \& Vietnam General Department of Vocational Training, Hanoi.

UNDP(2012), Green Economy in Action: articles and Experts that illustrate Green Economy and Sustainable Development Efforts, UNDP

UNDP(2012), Integrating Energy Access and Employment Creation to Accelerte Progress on the MDGs in Sub-Saharan Africa, UNDP

UNDP(2008), Social Enterprise: A new model for poverty reduction and employment generation-An examination of the concept and practice in Europe and the Commonwealth of Independent States, EMES, UNDP.

UNDP Mongolia(2007), Mongolia Human Development Report 2007, Employment and Poverty in Mongolia

Varma, Adarsh(2010), Estimating green jobs in Bangladesh: A report prepared by GHK for the International Labour Organisation, GHK

Wheelahan, Michael and Koenigson, Lennart(2006), JobsNet An Employment Sourcing and Delivery System in Sri Lanka, SIDA Evaluation, Asia Department, SIDA. 
Viet, Nguyen Quang \& The, Pham Xuan(2011), Vocational Training to meet Demends of small and medium enterprise, Labor and Social Publishing House.

Wheeler, D., McKague, K., and Thomson, J.(2003), Sustainable Livelihoods and the Private Sector: How Development Agencies Can Strengthen Sustainable Local Enterprise Network, Final Report, School of Business, York University.

\section{- 자료}

"Vietnam Vocational Training Report 2011", National Institute for Vocational Training(NIVT) \& General Department of Vocational Training(GDVT), Vietnam Ministry of Labor, Invalids and Social Affairs(MOLISA), vietnam.

General Statistics Office(GSO), Vietnam

UNESCO-IBE, 2011, World Data on Education: Vietnam, 7th. Ed. 2010/11 